\title{
Designing a network of critical zone observatories to explore the living skin of the terrestrial Earth
}

\author{
Susan L. Brantley ${ }^{1}$, William H. McDowell ${ }^{2}$, William E. Dietrich ${ }^{3}$, Timothy S. White ${ }^{1}$, Praveen Kumar ${ }^{4}$, \\ Suzanne P. Anderson ${ }^{5}$, Jon Chorover ${ }^{6}$, Kathleen Ann Lohse ${ }^{7}$, Roger C. Bales ${ }^{8}$, Daniel D. Richter ${ }^{9}$, \\ Gordon Grant $^{10}$, and Jérôme Gaillardet ${ }^{11}$ \\ ${ }^{1}$ Earth and Environmental Systems Institute, Department of Geosciences, The Pennsylvania State University, \\ Univ. Park, PA 16802, USA \\ ${ }^{2}$ Department of Natural Resources and the Environment, University of New Hampshire, \\ Durham, NH, 03824, USA \\ ${ }^{3}$ Department of Earth and Planetary Science, University of California, Berkeley, CA 94720, USA \\ ${ }^{4}$ Department of Civil and Environmental Engineering, and Department of Atmospheric Science, \\ University of Illinois, Urbana, Illinois 61801, USA \\ ${ }^{5}$ Department of Geography, Institute of Arctic and Alpine Research (INSTAAR), \\ University of Colorado, CO 80309-0450, USA \\ ${ }^{6}$ Department of Soil, Water and Environmental Science, University of Arizona, Tucson, AZ 85750, USA \\ ${ }^{7}$ Department of Biological Sciences, Idaho State University, Pocatello, ID 83209, USA \\ ${ }^{8}$ Sierra Nevada Research Institute and School of Engineering, University of California, Merced 94530, USA \\ ${ }^{9}$ Nicholas School of the Environment, Duke University, Durham, North Carolina 27708, USA \\ ${ }^{10}$ Pacific Northwest Research Station, USDA Forest Service, Corvallis, OR 97331, USA \\ ${ }^{11}$ Institut de Physique du Globe de Paris, Sorbonne Paris Cité, CNRS, Paris, France
}

Correspondence: Susan L. Brantley (brantley@eesi.psu.edu)

Received: 2 June 2017 - Discussion started: 19 June 2017

Revised: 5 October 2017 - Accepted: 22 October 2017 - Published: 18 December 2017

Abstract. The critical zone (CZ), the dynamic living skin of the Earth, extends from the top of the vegetative canopy through the soil and down to fresh bedrock and the bottom of the groundwater. All humans live in and depend on the CZ. This zone has three co-evolving surfaces: the top of the vegetative canopy, the ground surface, and a deep subsurface below which Earth's materials are unweathered. The network of nine CZ observatories supported by the US National Science Foundation has made advances in three broad areas of CZ research relating to the co-evolving surfaces. First, monitoring has revealed how natural and anthropogenic inputs at the vegetation canopy and ground surface cause subsurface responses in water, regolith structure, minerals, and biotic activity to considerable depths. This response, in turn, impacts aboveground biota and climate. Second, drilling and geophysical imaging now reveal how the deep subsurface of the $\mathrm{CZ}$ varies across landscapes, which in turn influences aboveground ecosystems. Third, several new mechanistic models now provide quantitative predictions of the spatial structure of the subsurface of the CZ.

Many countries fund critical zone observatories (CZOs) to measure the fluxes of solutes, water, energy, gases, and sediments in the $\mathrm{CZ}$ and some relate these observations to the histories of those fluxes recorded in landforms, biota, soils, sediments, and rocks. Each US observatory has succeeded in (i) synthesizing research across disciplines into convergent approaches; (ii) providing long-term measurements to compare across sites; (iii) testing and developing models; (iv) collecting and measuring baseline data for comparison to catastrophic events; (v) stimulating new process-based hypotheses; (vi) catalyzing development of new techniques and instrumentation; (vii) informing the public about the $\mathrm{CZ}$; (viii) mentoring students and teaching about emerging multidisciplinary $\mathrm{CZ}$ science; and (ix) discovering new insights about the CZ. Many of these activities can only be accomplished with observatories. Here we review the CZO enterprise in the United States and identify how such observatories 
could operate in the future as a network designed to generate critical scientific insights. Specifically, we recognize the need for the network to study network-level questions, expand the environments under investigation, accommodate both hypothesis testing and monitoring, and involve more stakeholders. We propose a driving question for future CZ science and a "hubs-and-campaigns" model to address that question and target the CZ as one unit. Only with such integrative efforts will we learn to steward the life-sustaining critical zone now and into the future.

\section{Introduction}

Humans live on Earth's surface - a surface that changes on timescales ranging from milliseconds to millions of years. Understanding how to sustain a growing human population on this changing substrate while simultaneously sustaining diverse ecosystems is a great challenge for scientists and decision makers (Millennium Ecosystem Assessment Board, 2005; Easterling, 2007). In recognition of the critical nature of Earth's surface, the US National Research Council defined the zone from the upper vegetative canopy through groundwater as the critical zone (CZ) and identified study of this $\mathrm{CZ}$ as one of the basic research opportunities in the Earth sciences (US National Research Council Committee on Basic Research Opportunities in the Earth Sciences, 2001).

While the CZ was defined in 2001, only recently has it been recognized as a distinct co-evolving entity driven by physical, chemical, and biological processes that sustain life. To tackle the $\mathrm{CZ}$ for the first time as an entity - rather than study pieces of it separately - is a paradigm shift in science (Fig. 1). Currently, understanding this zone requires researchers drawn from many traditional disciplines including geology, hydrology, climate science, ecology, soil science, geochemistry, geomorphology, and social science to work in collaboration. In the future, it will be pursued not only by disciplinary researchers but also by new scientists trained to cross disciplines. $\mathrm{CZ}$ science uses a wide range of measurements as the foundation for advances in understanding and prediction. Scientists quantify fluxes of solutes, water, energy, gases, and sediments (SWEGS) as they are today and then compare them to the histories and impacts of those fluxes recorded over geological time in landforms, regolith structure, soils, and sediments. CZ scientists also relate these fluxes to natural and anthropogenic drivers as well as to the structure of the $\mathrm{CZ}$, including biota, soil, and regolith. In this way, models are developed that can scale $\mathrm{CZ}$ properties across the landscape and project the $\mathrm{CZ}$ changes across time into the future. From this endeavor has emerged the concept of critical zone science, a new paradigm shift that has been adopted around the world to investigate Earth's surface from canopy to bedrock in its entirety as one integrated unit.

CZ science typically has these attributes: (i) it targets Earth's surface from canopy through groundwater; (ii) it encompasses timescales from milliseconds (or less) to millions of years; and (iii) it incorporates insights from all relevant

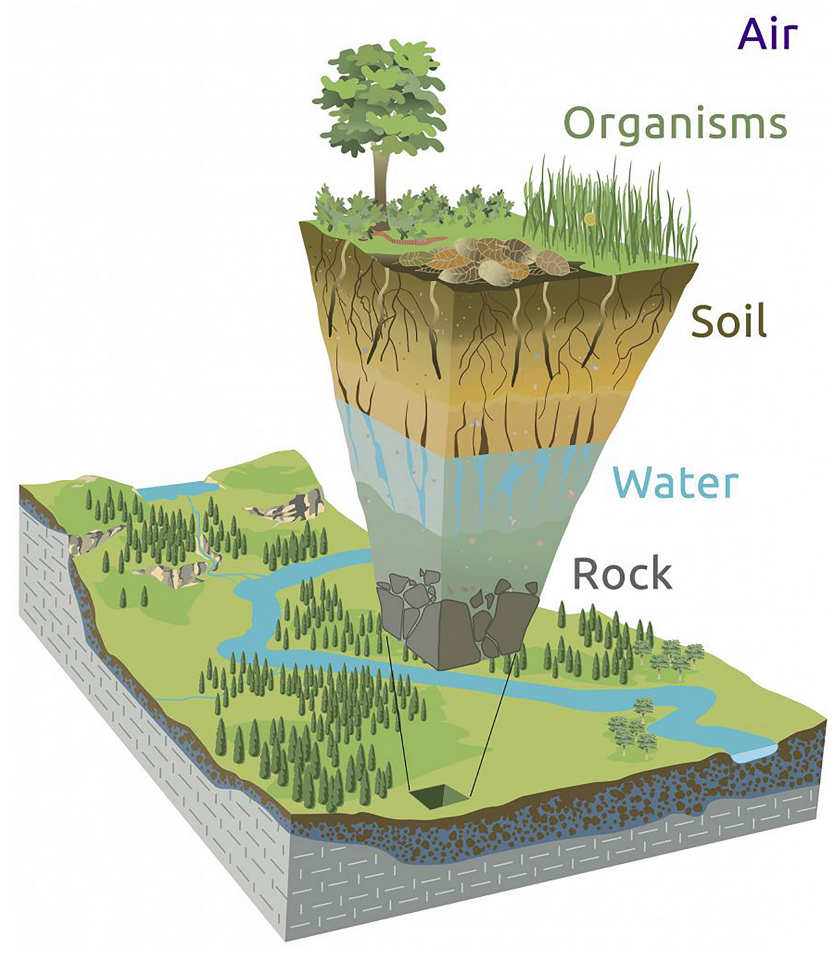

Figure 1. Understanding the critical zone requires harnessing insight from many disciplines on processes and fluxes from the top of the vegetation canopy down into the groundwater on all spatial scales across timescales from milliseconds to millennia. Figure reproduced from Chorover et al. (2007), artwork by R. Kindlimann.

disciplines. Some have described $\mathrm{CZ}$ science as an attempt to put more geology into watershed science, or the study of the interaction of rocks and ecosystems. Each of those descriptors falls short of the full complexity of understanding the $\mathrm{CZ}$ as an entity with its own identity.

In the United States, observatories to study the $\mathrm{CZ}$ have been established by the National Science Foundation (NSF). The physical scope of these US critical zone observatories (CZOs) varies, as some are defined by watershed boundaries, some by land use, others by the range of climate conditions, and still others by contrasts in lithology or geomorphic history. The common elements are (1) the focus on the entire above- and belowground $\mathrm{CZ}$ and its fluxes, (2) documentation of $\mathrm{CZ}$ structure, (3) mechanistic process studies, and (4) analysis of the history of the landscape that gave rise 


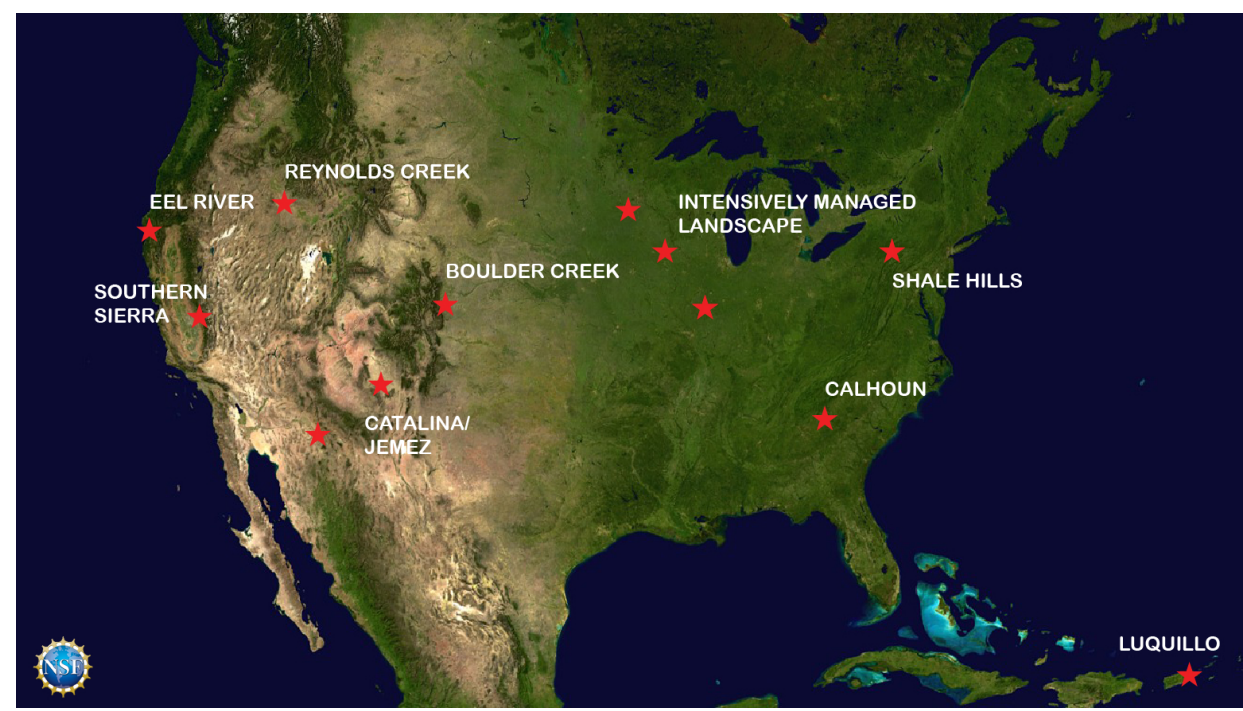

Figure 2. The current network of nine critical zone observatories funded in the United States to investigate all aspects of the critical zone. Abbreviations used in Table 2 include Eel River (ER), Southern Sierra (SS), Jemez-Catalina (JC), Boulder Creek (BC), Reynolds Creek (RC), Intensively Managed Landscapes (IML), Susquehanna Shale Hills (SH), Calhoun (CL), and Luquillo (L).

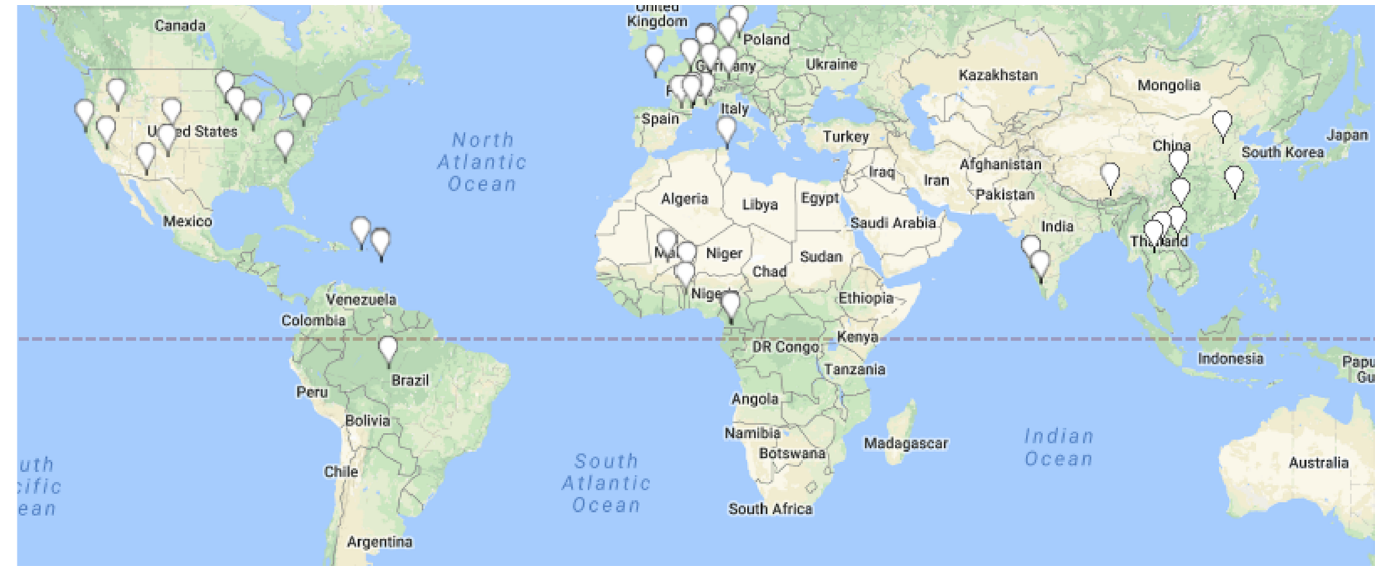

Figure 3. Location map of the 45 CZO locations in the United States, Germany (TERENO), France (RBV/CRITEX), UK, and China that have been registered on Site Seeker (http://www.czen.org/site_seeker). The sites in South America, Africa, India, and several in the Caribbean are operated by the French RBV/CRITEX program.

to its current structure. This last feature is a crucial aspect of CZOs that distinguishes them from previous studies that typically do not consider "deep time" (i.e., geologic time) and often fail to document the CZ below the upper soil. Previous papers have described how researchers have grappled with the establishment of a measurement design at a specific $\mathrm{CZO}$, with the overall data needs of CZOs, and with a modeling framework that might be used to tackle the complexity of the timescales under consideration (Horsbaugh et al., 2008; Duffy et al., 2014; Niu et al., 2014; Brantley et al., 2016).

Over the last decade of study at individual CZOs, crossCZO science has emerged and begun to unite the observatories into a CZO network with the capacity to test hypotheses across a larger parameter space than can be represented by any single CZO. As a result, network-level science has begun to emerge and provide opportunities that were not possible in the past. In this paper, we review the evolution of $\mathrm{CZ}$ science as an interdisciplinary experiment. We take stock of successes and weaknesses. The goal of the paper is to strategize about how to design a better CZO network to maximize future opportunities in $\mathrm{CZ}$ science at the levels of the individual observer, the observatory, the network, and the broader Earth surface science community. Specifically, we address the broad question of what programs and infrastructure are needed by the community to understand the $\mathrm{CZ}$ of the future. The review is focused on activities and results of this endeavor to date in the United States. We acknowledge the many other observatory networks around the world 
(http://www.czen.org/site_seeker) and invite future papers on how those other networks are constituted and how the various observatory systems can work together.

One way to review the US program to date is to summarize performance through quantitative metrics. As manifested today, the program funds nine CZOs situated across a range of landscapes (Fig. 2). In addition, interdisciplinary field observatories that host $\mathrm{CZ}$ science involve thousands of interdisciplinary investigators in more than 25 nations (Fig. 3) (Giardino and Houser, 2015). Other metrics further highlight how CZ science has energized people and approaches in the United States and abroad (Tables 1, 2, 3, 4). Indeed, the term critical zone has been used in 925 papers as of June 2017, in title, abstract, or keyword as recorded in Web of Science. The term has even entered the realm of geopolitics (Latour, 2014) and been defined in scientific dictionaries (White and Sharkey, 2016). This is remarkable given that CZ science as an idea only dates from 2001. Less quantifiable, however, is the impact of the idea of the CZ: for example, one country hosting one of the longest-functioning observatory networks in and across the world (France) is now specifically promoting communication among disciplines and sites. Researchers within that network have pointed to the internationally emerging paradigm of the $\mathrm{CZ}$ as a driver for this new level of communication. Thus, quantitative metrics such as those in Table 1 do not fully illustrate the way $\mathrm{CZ}$ science has impacted science. In the rest of the paper we therefore discuss the evolution of observatories in environmental science, other mechanisms for studying the $\mathrm{CZ}$, the history of the CZO program, the nine roles of CZOs, and CZO measurements and models. We finish by discussing the strengths and weaknesses of the $\mathrm{CZO}$ approach to date and show how network-level understanding is starting to emerge. In the last section we consider an overarching question to drive future $\mathrm{CZ}$ science, and we propose a new topology for the $\mathrm{CZO}$ network.

\section{Historical context for environmental observatories and networks}

It is useful to place the $\mathrm{CZ}$ enterprise broadly into the context of environmental science. The differentiated scientific disciplines largely did not yet exist until the 1900s, and the earliest natural scientists therefore tended to be multidisciplinary (e.g., Forbes, 1887; CFIR CSEPP, 2005; Warkentin, 2006; Berner, 2012; Riebe et al., 2016). These researchers early on began to articulate the need for place-based, integrative science. This has led to a rich history of diverse, place-based, experimental, and long-term observation sites in the United States and world.

Many of these observatories were established to investigate the impacts of specific land use activities. One of the first was the Rothamsted Experimental Station in Harpenden, England, founded in 1843 to study the effects of fertilizers on crops. Not until 1910 did the concept of using paired watersheds to investigate the hydrologic and geomorphic impacts of land use treatments within the United States begin when a pair of small instrumented catchments were instituted for monitoring to evaluate changes in stream flow and sediment yield at Watson Wheel Gap, Colorado (Van Haveren, 1988).

As human population and land use increased, researchers began to compare pristine sites to human-impacted sites, and they began emphasizing the need for long-term measurements (Leopold, 1962). The US Geological Survey thus developed a hydrologic benchmark network (HBN) of 57 basins (Cobb and Biesecker, 1971) to make long-term hydrologic measurements. The mandate of the HBN was expanded in 2011 to include long-term observations not only of stream flow and water quality but also of soil chemistry and aquatic ecology (McHale et al., 2014). There are 37 hydrologic benchmark watersheds that are still maintained (Mast, 2013), but the original vision to also characterize vegetation and geology has remained unfulfilled.

The paired-watershed approach pioneered in Watson Wheel Gap, Colorado, was replicated much later in many other locations in the United States, including Coweeta Hydrologic Laboratory (North Carolina), Hubbard Brook (New Hampshire), Reynolds Creek Experimental Watershed (Idaho), and the H.J. Andrews Experimental Forest (Oregon) among others. These pioneer sites, in turn, led to the establishment of over 70 Experimental Forests and Rangelands sites that focus on fundamental and applied questions spanning hydrology, silviculture, soil science, and climate research (Lugo et al., 2006).

In the early 1980s, as academic scientists pointed out the difficulties of answering questions about long-term natural processes given the realities of short-term funding (Bormann and Likens, 1979; Callahan, 1984), the US National Science Foundation Directorate of Biological Sciences created the Long-Term Ecological Research (LTER) program to carry out observation-based research across a network of sites that spanned the major biotic regions of North America. These efforts were aided by early work of the US Forest Service to understand watershed hydrology (Swank and Crossley, 1988). The LTER effort was initiated predominantly by ecosystem ecologists asking questions about organisms with long life cycles, including how they are maintained by natural water and nutrient fluxes in the face of acute environmental changes that are long term as well as episodic (Dodds and al., 2012). Although not exclusively based on the study of watersheds as pioneered in the late 1960s (Bormann and Likens, 1967), many LTER efforts follow a model that emphasizes the study of energy, water, and material flows through a watershed (Hynes, 1975). As of 2017, the LTER network contains 28 LTER programs and is beginning to emphasize the need to incorporate social science (Ohl et al., 2010).

A big step was taken in 1991 toward incorporating geology into these largely water-land use-ecology observatories when the US Geological Survey inaugurated the Wa- 
Table 1. Metrics enumerating the US CZO experiment.

\begin{tabular}{lr}
\hline CZOs in the United States & 9 \\
CZOs worldwide & $45^{\mathrm{a}}$ \\
Countries with interdisciplinary field observatories hosting CZ science $^{\mathrm{b}}$ & 25 \\
Papers citing critical zone in keyword WOS as of $2017^{\mathrm{c}}$ & 926 \\
Papers listing critical zone in title in WOS as of 2017 & 242 \\
Postdoctoral students educated at CZOs in 2015 & 39 \\
Graduate students educated at CZOs in 2015 & 186 \\
Undergraduate students educated at CZOs in 2015 & 106 \\
\hline
\end{tabular}

a Includes Germany (TERENO), France (RBV/CRITEX), UK, and China. ${ }^{\mathrm{b}}$ Giardano and

Houser (2015). ${ }^{\mathrm{c}}$ Papers returned through searching Web of Science (WOS) as of 28 May 2017 that

include "critical zone" in title or key word or abstract, etc. (not including abstracts for meetings).

Table 2. Common measurements made in the CZO network in the United States.

\begin{tabular}{|c|c|c|c|c|c|c|c|c|c|}
\hline Critical Zone Observatory - measurement type & $\begin{array}{l}\text { Boulder } \\
\text { Creek }\end{array}$ & $\begin{array}{l}\text { Cal- } \\
\text { houn }\end{array}$ & $\begin{array}{l}\text { Catalina- } \\
\text { Jemez }\end{array}$ & $\begin{array}{l}\text { Eel } \\
\text { River }\end{array}$ & $\begin{array}{l}\text { Intensively } \\
\text { Managed } \\
\text { Landscapes }\end{array}$ & Luquillo & $\begin{array}{l}\text { Reynolds } \\
\text { Creek }\end{array}$ & $\begin{array}{c}\text { Susque. } \\
\text { Shale } \\
\text { Hills }\end{array}$ & $\begin{array}{l}\text { S. } \\
\text { Sierra }\end{array}$ \\
\hline \multicolumn{10}{|l|}{ Land-atmosphere exchange } \\
\hline Lidar & $\mathrm{X}$ & $\mathrm{X}$ & $\mathrm{X}$ & $\mathrm{X}$ & $\mathrm{X}$ & $\mathrm{X}$ & $\mathrm{Y}, \mathrm{Z}$ & $\mathrm{X}$ & $\mathrm{X}, \mathrm{Y}$ \\
\hline Eddy flux & $\mathrm{Y}$ & $\mathrm{Z}$ & $X$ & & $\mathrm{X}, \mathrm{Y}, \mathrm{Z}$ & & $\mathrm{Y}$ & $\mathrm{X}$ & $\mathrm{X}, \mathrm{Y}, \mathrm{Z}$ \\
\hline Wind speed and direction & $\mathrm{X}$ & $\mathrm{Z}$ & $X$ & $\mathrm{X}$ & $\mathrm{X}, \mathrm{Y}$ & $\mathrm{Y}$ & $\mathrm{Y}$ & $\mathrm{X}$ & $\mathrm{X}$ \\
\hline Precipitation and throughfall & $\mathrm{X}$ & $\mathrm{X}, \mathrm{Z}$ & $\mathrm{X}$ & $\mathrm{X}$ & $\mathrm{X}, \mathrm{Y}$ & $\mathrm{Y}$ & Y & $\mathrm{X}$ & $\mathrm{X}, \mathrm{Y}$ \\
\hline Wet deposition and bulk deposition & $\mathrm{X}$ & $\mathrm{Z}$ & $\mathrm{X}$ & & Y & $\mathrm{Y}$ & $\mathrm{Y}$ & $\mathrm{X}$ & $\mathrm{X}, \mathrm{Y}$ \\
\hline Snowpack distribution and duration & $\mathrm{X}$ & & $\mathrm{X}$ & & & & & & $\mathrm{X}$ \\
\hline \multicolumn{10}{|l|}{ Vegetation and microbiota } \\
\hline Structure and function above and below biomass & $\mathrm{X}$ & $\mathrm{X}$ & $\mathrm{X}$ & $\mathrm{X}$ & $\mathrm{X}$ & $\mathrm{Y}$ & $\mathrm{Y}, \mathrm{Z}$ & $\mathrm{X}$ & $\mathrm{X}, \mathrm{Y}$ \\
\hline Microbial composition & $\mathrm{X}$ & $\mathrm{X}$ & $\mathrm{X}$ & $\mathrm{X}$ & $\mathrm{X}$ & $\mathrm{Y}$ & $\mathrm{X}$ & $\mathrm{x}$ & $\mathrm{X}$ \\
\hline $\begin{array}{l}\text { ET species composition and structure relationships } \\
\text { Soil (vadose zone) }\end{array}$ & $\mathrm{Y}$ & $\mathrm{Z}$ & $\mathrm{X}$ & $\mathrm{Y}$ & $\mathrm{Y}$ & & $\mathrm{Y}, \mathrm{Z}$ & $\mathrm{X}$ & $\mathrm{X}$ \\
\hline Solid - elemental composition and mineralogy & $\mathrm{X}$ & $\mathrm{X}$ & $\mathrm{X}$ & $\mathrm{X}$ & $\mathrm{X}$ & $\mathrm{X}$ & $\mathrm{Z}$ & $\mathrm{X}$ & $\mathrm{X}, \mathrm{Y}$ \\
\hline Solid - texture and physical characterization & $\mathrm{X}$ & $\mathrm{X}$ & $\mathrm{X}$ & $\mathrm{X}$ & $\mathrm{X}$ & $X$ & $\bar{Z}$ & $\mathrm{X}$ & $\mathrm{X}, \mathrm{Y}$ \\
\hline Solid - organic matter content & $\mathrm{X}$ & $\mathrm{X}$ & $\mathrm{X}$ & $\mathrm{X}$ & $\mathrm{X}$ & $\mathrm{X}$ & $\mathrm{Z}$ & $\mathrm{X}$ & $\mathrm{X}$ \\
\hline Solid - radiogenic isotope composition & $\mathrm{X}$ & $\mathrm{X}$ & $\mathrm{X}$ & & $\mathrm{X}$ & $\mathrm{X}$ & & $\mathrm{X}$ & $\mathrm{X}, \mathrm{Z}$ \\
\hline Fluid - soil moisture (sensors) & $\mathrm{X}$ & $\mathrm{X}$ & $\mathrm{X}$ & $\mathrm{X}$ & $\mathrm{X}$ & $\mathrm{X}$ & $\mathrm{Y}, \mathrm{Z}$ & $\mathrm{X}$ & $\mathrm{X}$ \\
\hline Fluid - soil temperature (sensors) & $\mathrm{X}$ & $\mathrm{X}$ & $X$ & $\mathrm{X}$ & $\mathrm{X}$ & $\mathrm{X}$ & $\mathrm{Y}, \mathrm{Z}$ & $\mathrm{X}$ & $\mathrm{X}$ \\
\hline Fluid - soil solution chemistry (samplers) & $\mathrm{X}$ & $\mathrm{Z}$ & $\mathrm{X}$ & & $\mathrm{X}$ & $\mathrm{X}$ & & $\mathrm{X}$ & $\mathrm{X}, \mathrm{Y}$ \\
\hline Fluid - soil gas chemistry (samplers and sensors) & & $\mathrm{X}$ & $\mathrm{X}$ & $\mathrm{X}$ & & $\mathrm{X}, \mathrm{Y}$ & $\mathrm{Z}$ & $\mathrm{X}$ & $\mathrm{X}$ \\
\hline \multicolumn{10}{|l|}{ Saprolite and bedrock (saturated zone) } \\
\hline Solid - petrology and mineralogy & $\mathrm{X}$ & $\mathrm{X}$ & $\mathrm{X}$ & $\mathrm{X}$ & $\mathrm{Y}$ & $\mathrm{X}$ & $\mathrm{Z}$ & $\mathrm{X}$ & $\mathrm{X}, \mathrm{Z}$ \\
\hline Solid - elemental composition and organic matter content & $\mathrm{X}$ & $\mathrm{X}$ & $\mathrm{X}$ & $\mathrm{X}$ & $\mathrm{X}$ & $\mathrm{X}$ & $\mathrm{Z}$ & $\mathrm{X}$ & $\mathrm{X}, \mathrm{Z}$ \\
\hline Solid - texture, physical and architectural constraints & $\mathrm{X}$ & $\mathrm{X}$ & $\mathrm{X}$ & $\mathrm{X}$ & $\mathrm{X}$ & $\mathrm{X}$ & $\mathrm{Z}$ & $\mathrm{X}$ & $\mathrm{X}$ \\
\hline Fluid - potentiometric head, temperature (sensors) & $\mathrm{X}$ & $\mathrm{X}$ & $\mathrm{X}$ & $\mathrm{X}$ & $\mathrm{X}$ & $\mathrm{X}$ & $\mathrm{Y}$ & $\mathrm{X}$ & $\mathrm{X}$ \\
\hline Fluid - groundwater chemistry (samplers and sensors) & $\mathrm{X}$ & $\mathrm{X}$ & $\mathrm{X}$ & $\mathrm{X}$ & $\mathrm{X}$ & $X$ & $\mathrm{Y}$ & $\mathrm{X}$ & $\mathrm{X}$ \\
\hline Fluid - saprolite and weathered bedrock gas chemistry & & $\mathrm{X}$ & $\mathrm{Z}$ & $\mathrm{X}$ & & & & $\mathrm{x}$ & \\
\hline Geophysical surveys - depth to bedrock & $\mathrm{X}$ & $\mathrm{X}$ & $\mathrm{X}$ & & $\mathrm{X}$ & $\mathrm{X}$ & & $\mathrm{X}$ & $\mathrm{X}$ \\
\hline \multicolumn{10}{|l|}{ Surface water } \\
\hline Instantaneous discharge & $\mathrm{X}$ & $\mathrm{X}$ & $X$ & $\mathrm{X}$ & $\mathrm{X}, \mathrm{Y}$ & $\mathrm{X}, \mathrm{Y}, \mathrm{Z}$ & $\mathrm{Y}$ & $\mathrm{X}$ & $\mathrm{X}, \mathrm{Y}$ \\
\hline Stable isotopes of water & $\mathrm{X}$ & $\mathrm{X}$ & $\mathrm{X}$ & & $\mathrm{X}$ & $\mathrm{X}$ & & $\mathrm{X}$ & $\mathrm{X}$ \\
\hline Stream water chemistry (samplers and sensors) & $\mathrm{X}$ & $\mathrm{X}$ & $\mathrm{X}$ & $\mathrm{X}$ & $\mathrm{X}$ & $\mathrm{X}, \mathrm{Y}, \mathrm{Z}$ & $\mathrm{Z}$ & $\mathrm{X}$ & $\mathrm{X}, \mathrm{Y}$ \\
\hline Sediments (samplers and sensors) & $\mathrm{X}$ & $\mathrm{X}$ & $\mathrm{X}$ & $\mathrm{X}$ & $\mathrm{X}$ & $\mathrm{X}, \mathrm{Y}, \mathrm{Z}$ & $\mathrm{Y}, \mathrm{Z}$ & $\mathrm{X}$ & $\mathrm{Y}, \mathrm{X}$ \\
\hline Extent of wetted channel & & & & $\mathrm{X}$ & & & & & $\mathrm{Y}, \mathrm{X}$ \\
\hline Aquatic biota (invertebrates, fish, etc.) & & & & $\mathrm{X}$ & & $\mathrm{Y}$ & & & $\mathrm{Y}$ \\
\hline \multicolumn{10}{|l|}{ Age or rate constraints } \\
\hline Cosmogenic radionuclides & $\mathrm{X}$ & $\mathrm{X}$ & $\mathrm{X}$ & & & $\mathrm{X}$ & & $\mathrm{X}$ & $\mathrm{X}$ \\
\hline $\mathrm{C}$ ages & $\mathrm{X}$ & $\mathrm{X}$ & $X$ & & & $\mathrm{X}$ & & $\mathrm{X}$ & \\
\hline Optically stimulated luminescence ages & $\mathrm{X}$ & & & & & & & & \\
\hline
\end{tabular}

$\mathrm{X}$ : instrumentation in place or sampling is occurring, owned, and operated by the CZO. Y indicates instrumentation is currently in place, owned, and operated by a partner of the CZO. Z indicates that it is planned to be installed or implemented in the future by the CZO. 
Table 3. Models used by the US CZOs (observatory abbreviations in Fig. 2).

\begin{tabular}{|c|c|c|c|}
\hline Model name & Systems modeled & $\begin{array}{c}\text { Possible X-CZO } \\
\text { application? }\end{array}$ & $\begin{array}{c}\text { CZOs } \\
\text { using model }\end{array}$ \\
\hline PIHM & Hydrology & $\mathrm{X}$ & $\mathrm{CR}, \mathrm{SH}, \mathrm{CL}$ \\
\hline Flux-PIHM & Hydrology, land-atmosphere & $\mathrm{X}$ & $\mathrm{SH}$ \\
\hline tRIBS & Hydrology & & LQ, CL \\
\hline hsB-SM & Hydrology & & CJ \\
\hline VS2D & Unsaturated hydrology & & $\mathrm{BC}$ \\
\hline Dhara & Near surface critical zone & $\mathrm{X}$ & IML, SH \\
\hline Optimal sensing & Soil moisture & & CL \\
\hline Hydropedo Toolbox & Soil moisture & & $\mathrm{SH}$ \\
\hline OTIS & Streambed hydrologic exchange & & SH \\
\hline Alpine glaciers $1 \& 2 \mathrm{~d}$ & Ice motion & & $\mathrm{BC}$ \\
\hline Fluid exchange & Estuary fluid flux & & $\mathrm{CR}$ \\
\hline PHREEQC & Aqueous geochemistry & & LQ \\
\hline WITCH & Weathering & $\mathrm{X}$ & $\mathrm{SH}, \mathrm{CL}$ \\
\hline ROMS & Ocean & & EL \\
\hline WRF & Weather forecasting & & $\mathrm{EL}, \mathrm{RC}$ \\
\hline ISNOBAL & Snow cover mass & & $\mathrm{RC}, \mathrm{SS}$ \\
\hline SHAW & Heat and water fluxes & & $\mathrm{RC}$ \\
\hline CHILD & Erosion, sediment transport, surface evolution & $\mathrm{X}$ & $\mathrm{BC}, \mathrm{CL}$ \\
\hline SOrCERO & Erosion and deposition & & CL \\
\hline Digital glacier bed & Elevation of glacier bed & & $\mathrm{BC}$ \\
\hline Gully erosion profiler & Channel profile evolution & & $\mathrm{BC}$ \\
\hline Hillslope trajectory & Erosion & & $\mathrm{BC}$ \\
\hline Range and basin & Mountain evolution & & $\mathrm{BC}$ \\
\hline Landlab & General 2-D models & & $\mathrm{BC}$ \\
\hline FEMDOC-2D & Hillslope DOC transport & & $\mathrm{CR}$ \\
\hline IDOCM_1D & Heat and DOC in soils & & $\mathrm{CR}$ \\
\hline CENTURY & Soil carbon & & LQ \\
\hline $\mathrm{CN}$ reforest dynamics & Tree and soil $\mathrm{C}$ and $\mathrm{N}$ & & CL \\
\hline BIOME BGC & Carbon & & $\mathrm{SH}, \mathrm{RC}$ \\
\hline Plant-soil feedback & Plant-soil, soil production & & CL \\
\hline Root deformation & Soil deformation from roots & & $\mathrm{BC}$ \\
\hline GASH & ET and throughfall & & LQ \\
\hline NPZD & Ecosystem & & EL \\
\hline PIHMSed & Water and sediment transport, uplift, weathering & $\mathrm{X}$ & $\mathrm{SH}$ \\
\hline PIHM-DOC & Hydrology, dissolved organic carbon & & $\mathrm{CR}, \mathrm{SH}$ \\
\hline TIMS & Hydrology + microbio-geochem-geomorph-ecology & $\mathrm{X}$ & CJ \\
\hline RHESSys & Hydrology, ecology & $\mathrm{X}$ & SS \\
\hline AWESOM & Atmosphere-watershed-ecology-stream-ocean & $\mathrm{X}$ & EL \\
\hline tRIBS-ECO & Hydrology, erosion, soil C & & CL \\
\hline $\begin{array}{l}\text { WEPP/CENTURY-WEPP/ } \\
\text { WEPP-Rill1D(3ST1D) }\end{array}$ & Soil erosion, biogeochemistry & $\mathrm{X}$ & IML \\
\hline OpenFOAM/BioChemFOAM & Riverine transport & $\mathrm{X}$ & IML \\
\hline CRUNCH & Reactive transport & $\mathrm{X}$ & SH, IML, EL \\
\hline Delft3D & Surface-subsurface transport & $\mathrm{X}$ & EL \\
\hline Nays2D & Flood & $\mathrm{X}$ & IML \\
\hline
\end{tabular}


Table 4. A few emergent hypotheses from the CZO network.

(1) CZ architecture controls hydrologic and geochemical processes that drive concentration-discharge relationships in rivers.

(2) The depth to fresh bedrock across upland landscapes may be predictable from models that account for regional stress fields, advancing chemical reaction fronts, drainage of the fresh bedrock, and/or fracturing from freeze-thaw.

(3) Aspect differences can be used to reveal the mechanisms and effects of climate on the CZ.

(4) The deep microbial community is linked to overlying vegetation: microbial community is distinctly different under agriculture fields, brush, grassland, perennial forest and deciduous forest.

(5) The deep microbial community is linked to lithology: the microbial community is distinctly different on granite, basalt, shale, and sandstone.

(6) The deep architecture of the $\mathrm{CZ}$ controls water availability to plants and microbial communities, which in turn influence regional climates.

(7) Subsurface reaction fronts may often be used to map flow paths in the subsurface.

(8) Human impact in Intensively Managed Landscapes has resulted in a critical transition that has changed the landscape from primarily a transformation-dominated system characterized by long residence times of water, carbon, and nutrients to a transportdominated system characterized by fast movement of water, sediment, carbon, and nutrients through the landscape into receiving water bodies.

ter, Energy, and Biogeochemical Budgets (WEBB) program. WEBB targeted interactions among water, energy, and biogeochemical fluxes at five sites chosen at least partly on the basis of their inherent geological characteristics and relatively pristine condition.

Then, in 2008, another long-term research program was envisioned by agricultural researchers (Robertson et al., 2008). This vision resulted in the establishment of the LongTerm Agroecosystem Research (LTAR) program in 2011. This network, today including 18 LTAR programs, promotes long-term agricultural research facilities, experiments, and watershed-based studies focused on sustaining agriculture and increasing crop yields under changing climate conditions while minimizing or reversing any adverse environmental impacts (http://www.tucson.ars.ag.gov/ltar/).

The most recent addition to the development of observatories in the United States is the National Ecological Observatory Network (NEON). NEON is a US-wide, distributed observatory that aims to understand and forecast the impacts of climate change, land use, and invasive species on ecology and ecosystem fluxes by providing a research platform for investigator-initiated sensors, observations, and experiments that can provide consistent, continental, long-term, multiscaled data (Loescher et al., 2017). NEON has 84 sites across the United States. Like LTER, NEON is a program funded by the Directorate of Biological Sciences at NSF to study ecological change (Golz et al., 2016).

As in the United States, international observatory networks have also grown, many for substantially the same reasons that they grew in the United States - to study land use, water, and ecology. In at least one country (France), a network (OZCAR: Observatoires de la Zone Critique: applications et recherche) emphasizes individual disciplines at each observatory and provides as much as 50 years worth of data to enable research in some sites. The long-term, place-based ecological research that was pioneered by the LTER network in the United States has also been adopted by the broader international community in the International LTER (ILTER) network (Vanderbilt and Gaiser, 2017). Today, the European Commission is promoting an approach to develop a European Research Infrastructure in the form of a network associating CZOs, LTERs, and LTSERs. Here, LTSER stands for Long-Term Socio-Ecological Research, i.e., a network that also incorporates questions from social science. Indeed, many of the European countries maintain strong observatory infrastructures that are much more tightly linked with local stakeholders than observatories in the United States. This may result from the lack of truly "natural" territories in Europe, given the long history of development on the continent but also the willingness to co-construct research questions with stakeholders to build a sustainable environmental future.

\section{Non-observatory approaches used to study the CZ}

Just as observatory science was beginning with the Watson Wheel Gap observatory in the early 1900s, scientists also began to focus on portions of the Earth system that could be understood in a reductionist sense (Riebe et al., 2016). Eventually, small-grant funding to single investigators or small teams became the dominant mechanism to fund research to explore questions about the $\mathrm{CZ}$. This targeted approach further emphasized reductionism and served to grow the individual disciplines of geochemistry, geobiology, geomorphology, hydrology, soil science, ecology, meteorology, and others. Disciplinary growth in turn allowed relatively defined "monodisciplinary" paradigms to mature and led to the proliferation of disciplinary journals. For example, Web of Science currently indexes 225 journals in the fields of environmental sciences, 184 in geosciences, and 150 in ecology, with some journals cross-reported in more than one category. 
Through smaller funded projects, many different types of measurements were made. However, the measurements were completed at different sites and integration of observations into models was difficult to impossible. Advances in studying Earth's surface tended to be uneven because different sites were targeted and coordination among disciplinary approaches was lacking. Such fragmentation accentuated the need for observatories. Other mechanisms were also needed, however, as questions about environmental impacts on human health grew in the United States throughout the 1970s (CFIR CSEPP, 2005). Funding agencies began seeking teams of researchers to pursue campaigns - concerted, multi-investigator, multiyear projects - targeting focused hypotheses about landforms, soils, water, biota, and human health. Such campaigns culminated in global efforts such as the Millennium Ecosystems Assessment (Millennium Ecosystem Assessment Board, 2005) and the International Geosphere-Biosphere Program (IGBP). The latter initiative engaged 10000 scientists from more than 20 disciplines and 80 countries (CFIR CSEPP, 2005; Millennium Ecosystem Assessment Board, 2005).

Eventually, another type of funding mechanism to study the CZ emerged in the United States alongside observatory, single-investigator, and campaign-style science. Specifically, centers of excellence were funded to draw together scientists into institutions to focus on specific problems or approaches. One impetus for this was the inauguration in 1987 of the NSF Science and Technology Center program. This effort eventually supported two centers of special relevance to CZ research: SAHRA (Sustainability of semi-Arid Hydrology and Riparian Areas) and NCED (National Center for Earth-Surface Dynamics). NCED (2002 to 2012) focused on developing a quantitative, predictive Earth surface science by integrating geomorphology, ecology, hydrology, sedimentary geology, engineering, social sciences, and geochemistry by combining field, experiment, and computational approaches. NCED and its reincarnation as NCED2 after 2012 both emphasize predictive Earth surface science. A similarly ambitious institution, the National Center for Ecological Analysis and Synthesis (NCEAS), was established in 1995 as the first national synthesis center for ecology. Neither of these centers focused on the $\mathrm{CZ}$ as one single entity.

Other examples of institutionalized centers of excellence were also important in developing aspects of $\mathrm{CZ}$ science. For example, the Community Surface Dynamics Modeling System (CSDMS; http://csdms.colorado.edu/wiki/Main_ Page) is building and promoting a library of models for various Earth surface processes by supporting a broad community of modelers. The National Center for Airborne Laser Mapping (NCALM, established in 2003) provides researchquality airborne light detection and ranging (lidar) observations to the community. Another example is the Consortium of Universities for the Advancement of Hydrologic Science, Inc. (CUAHSI; https://www.cuahsi.org/), which aims to broadly advance hydrologic sciences across the United
States and its member universities. Other centers of excellence have been established to promote the use of instrumentation such as the NSF-funded Purdue Rare Isotope Measurement Laboratory (PRIME Lab), a dedicated research and service facility for accelerator mass spectrometry including measurement and interpretation of cosmogenic isotopes.

\section{The CZO program}

Even with this variety of funding mechanisms for Earth and environmental science, no concerted nationwide effort emerged to tackle questions and to train students to target the $\mathrm{CZ}$ as one entity, incorporating the deep geological underpinnings and long-timescale perspectives. As a result, the environmental science that developed often had to rely on statistical approaches to explain variability instead of developing more fundamental explanations based on underlying geological heterogeneity and its origins. Recognizing the need to emphasize the geological underpinnings of place-based science in the late 2000s, researchers within the water, soil, geochemistry, and geomorphology communities began articulating a need for integrated science across the entire zone from canopy to bedrock to incorporate the full significance of the underlying geology (Anderson et al., 2004; Brantley et al., 2006; Chorover et al., 2007; US Committee on Integrated Observations for Hydrologic and Related Sciences, 2008; US Steering Committee for Frontiers in Soil Science, 2009; US National Research Council, 2010; Banwart et al., 2011; Committee on New Research Opportunities in the Earth Sciences at the National Science Foundation, 2012; White and Sharkey, 2016).

Eventually the need to study the $\mathrm{CZ}$ as one integrated entity resulted in the NSF program establishing the Critical Zone Observatory program in 2007 (White et al., 2015). In this initial phase, three CZOs were funded (Anderson et al., 2008). Three more CZOs were funded 2 years later. By 2013 this number had grown to nine observatories supported through a competitive selection process. In addition to the expansion of sites in 2013, a CZO National Office (NO) was established by the NSF in 2014 through a competitive process, with the intent of providing the CZO network with an administrative structure for furthering coordination (White et al., 2015). The number of CZOs has remained stable through 2017.

Inauguration of the CZO program implicitly defined the term critical zone observatory to be distinct within the long history of observatories in the United States and abroad as an observatory that promotes study of the entire $\mathrm{CZ}$ as one entity. As implemented today, CZOs are sites or closely connected sets of sites with no required size or specified range of conditions. In fact, the physical scope of a CZO is set only by the fundamental questions driving the establishment of the observatory. A fundamental characteristic of a CZO is that it is able to operate over a long enough period to quantify 
controlling mechanisms thoroughly and to capture temporal trends that reveal how the $\mathrm{CZ}$ operates. Two more characteristics of a CZO are that it is amenable to study by many disciplines and that it integrates understanding of long- and short-timescale phenomena. Finally, each CZO operates as an adaptive and agile hypothesis-testing machine, not simply a monitoring program. As CZOs developed in the United States, they began to play nine important roles within the environmental scientific endeavor. These are described in the next section.

\section{The nine emergent roles of CZOs}

Here the nine important roles of an observatory are described with examples of scientific results from across the CZO network today.

First, CZOs act as synthesizers of interdisciplinary research into convergent approaches at one specific site that lead to novel understanding and ultimately result in more deeply informed generalized and predictive understanding (Rasmussen et al., 2011). In other words, observatories induce scientists from different disciplines to make measurements using different disciplinary approaches at the same location instead of making them at disparate sites, driving cross-disciplinary understanding in describing $\mathrm{CZ}$ function (Hynek et al., 2017; Sullivan et al., 2016; Yan et al., 2017; Chen et al., 2017, in press). At first, much of the synthesis crossed only two disciplines at a time: for example, several papers emphasized how geomorphological concepts related to erosion must be incorporated to understand chemical weathering, and vice versa (Rempe and Dietrich, 2014; Riebe et al., 2016). Likewise, researchers have related tree roots to water cycling (Vrettas and Fung, 2015). Now, researchers are targeting multidisciplinary aspects of $\mathrm{CZ}$ entities. For example, at the Calhoun CZO, where the South Carolina landscape was severely eroded by cotton farming, logistic regression models treat market and policy conditions in the context of topographic characteristics (Coughlan et al., 2017). By fostering measurements from all disciplines in centralized places, CZOs are discovering not only how to cross disciplines but also how individual disciplines can converge.

Second, CZOs provide stable platforms for long-term measurements (Table 2). Some datasets synthesized by CZOs are now available for decades or several decades. For example, the Reynolds Creek CZO recently published 31 years of hourly data that are spatially distributed at $10 \mathrm{~m}$ resolution for air temperature, humidity, and precipitation (Kormos et al., 2016) and a 10-year dataset that spans the rainsnow transition (Enslin et al., 2016). Similarly, decreasing trends in water and energy influx in the Jemez CZO over the past 30 years were recently related to $\mathrm{CZ}$ structure (ZapataRios et al., 2016). Major changes in soil biogeochemistry have been documented by Calhoun CZO researchers over 50 years of reforestation in fields cultivated for cotton (Mobley et al., 2015). That CZO also spearheads an effort to recover archived data from three eroded watersheds that were farmed from the late 1940 s to 1962 - as well as to re-instrument the catchments. Many other multiyear measurements common to all CZOs enable hypothesis testing. For example, characterization of dissolved organic matter (DOM) measured with similar methodology across five CZOs revealed a strong role for $\mathrm{CZ}$ structure in setting the origin, composition, and fate of DOM in streams (Miller et al., 2016). In another example, a coordinated effort emerged to measure and understand the relationships among solute concentrations and water discharge in streams (e.g., Kirchner, 2003; Godsey et al., 2009). A special issue on the topic (Chorover et al., 2017) points the way toward the use of knowledge of subsurface structure to explain concentration-discharge behavior a priori.

Third, CZOs act as a stimulus and test bed for modeling and prediction. Modeling the $\mathrm{CZ}$ is a unique challenge in that models must address the coupling across timescales from seconds to millennia (Table 3). To tackle this challenge, CZOs both adapt existing models and develop new models. For example, one CZO is developing a hierarchy of modules to describe processes that occur over seconds to millennia (Duffy et al., 2014). For long-timescale processes, almost every CZO has proposed models of regolith formation, and many are summarized in a special issue (Riebe et al., 2016). On the shorter timescales, standard water or coupled land surface-air models have been tested and new modules developed (Table 3). To exploit high-resolution data such as lidar and hyperspectral measurements, modeling efforts explore micro-topographic and vegetation controls on soil moisture (Le et al., 2015; Le and Kumar, 2017) as well as biogeochemical changes in agricultural landscapes (Woo and Kumar, 2017). Researchers have likewise developed a energy-balance snowmelt model that is now being used with remotely sensed data for water supply forecasting (Painter et al., 2016). In other integrative efforts, researchers are modeling how hydraulic conductivity, root water uptake efficiency, and hydraulic redistribution by plants sustain evapotranspiration through dry seasons (Quijano et al., 2012, 2013; Vrettas and Fung, 2015). Work at the Luquillo CZO has supported interpretations of the controls on bed load grain size and channel dimensions for rivers (Phillips and Jerolmack, 2016). Researchers at the Calhoun CZO use distributive models to explore relationships between topographic variations and the landscape's capacity to serve as an atmospheric carbon source or sink (Dialyanis et al., 2015).

Fourth, CZOs act as baselines to understand and teach about the impact of catastrophic events. For example, two western CZOs in the United States have studied the impacts of wildfire on soil microbiota (Weber et al., 2014), sediment yields (Orem and Pelletier, 2016), snow accumulation (Harpold et al., 2014), and water quality (Murphy et al., 2012; Reale et al., 2015). Likewise, effects of the 2013 Colorado Front Range storm (Gochis et al., 2015) on debris flows 
(Anderson et al., 2015), soil moisture (Ebel et al., 2015), cosmogenic radionuclides (Foster and Anderson, 2016), and concentration-discharge behavior (Rue et al., 2017) were studied at the Boulder Creek CZO. A flash flood within Boulder Creek CZO in 2016 instigated analysis of Horton overland flow in these landscapes (Klein et al., 2017). CZOs that experience catastrophic events use the baseline data captured before the event to place the impact into perspective. An additional attribute is that such natural disasters engender public interest in research: research on the 2013 Colorado Front Range storm from the Boulder Creek CZO and wildfire research from three CZOs has been featured in radio, press, and public forums. The important role of observatories in recording catastrophic events was reinforced by Hurricanes Irma and Maria, which brought winds of up to $250 \mathrm{~km} \mathrm{~h}^{-1}$ and enormous rainfall to the island of Puerto Rico in September 2017. The Luquillo CZO quantified winds, rains, and stormflows and will document Maria's impacts on forest canopies, accelerated tree throw, and mass hillslope movements for many years to come.

Fifth, CZOs act as the organizing design for systematic campaigns to investigate process-based mechanisms across different types of CZ. One example of this is the initiative in which every CZO in the United States pursued geophysical measurements. Many papers have been published exemplifying this approach to map out the subsurface architecture (Befus et al., 2011; Holbrook et al., 2014; Orlando et al., 2015; Olyphant et al., 2016). Now, geophysicists travel among CZOs to image the subsurface with a battery of instruments to image the belowground landscape (St. Clair et al., 2015). In another example, after the Boulder Creek CZO began emphasizing slope aspect as a useful natural experiment to examine controls on $\mathrm{CZ}$ architecture and function in 2009, similar analyses at other CZOs led to highlighted linkages among aspect, water, biota, regolith structure, and episodic events (West et al., 2014; Ebel et al., 2015; Pelletier et al., 2017). Finally, a deep drilling project ("drill the ridge") was proposed and then pursued at many CZOs, and these data in turn led to a special issue describing regolith formation (Riebe et al., 2016). Successful campaigns have also been mounted to investigate mountain snow and water balance (Harpold et al., 2014).

Sixth, CZOs act as catalysts for the development of new techniques and instrumentation that can then be tested globally. For example, at the Eel River CZO, a unique vadose zone monitoring system (VMS) consisting of holes drilled into a hill at $55^{\circ}$ relative to the horizontal has been installed to monitor for temperature, pressure, and electrical conductivity. The VMS probes the generally inaccessible deep vadose zone to test reactive transport models incorporating gas and water chemistry (Druhan et al., 2017). At another CZO, experiments designed to improve management practices for erosion have elucidated controls on the concentration of carbon in eroded sediment and original soil (Papanicolaou et al., 2015). One CZO explores weathering reactions through the use of neutron scattering (NS) to analyze pores as small as nanometers in rocks (Navarre-Sitchler et al., 2013). Waterbalance instrumentation using robust wireless-sensor networks, developed at the Southern Sierra CZO (Kerkez et al., 2012), has been extended to the river-basin scale (Zhang et al., 2017) and is being deployed at other locations across the United States. An approach developed to scale annual evapotranspiration measured at flux towers across the broader forested landscape of the Sierra Nevada (Goulden et al., 2012) is also being applied to flux-tower sites and forested areas across the western United States.

Seventh, CZOs serve as hubs for informing regional resource-management decisions and for educating the public about societally relevant problems. For example, measurements of evapotranspiration made at one CZO and scaled across the Sierras provide a basis for estimating sustainable forest densities today and into the future when the climate will be warmer and drier (Goulden and Bales, 2014). Research on water resources is routinely communicated to water managers in California and the intermountain west by the Southern Sierra CZO through briefings, workshops, and data products. Results from Catalina-Jemez CZO studies of wildfire impacts on watershed-scale sediment transport are also being considered in the development of forest management strategies in two states. Research on snowpack and water resources by the Boulder Creek CZO has similarly been communicated in a series of workshops for water managers in Colorado, Utah, and Wyoming in 2015. In other parts of the country, the Eel River CZO documents controls on the spread of cyanobacteria in the Eel River, and information is disseminated in biannual gatherings of students, agency members, Native Americans, and practitioners. The IML CZO (see the caption of Fig. 2 for all CZO station abbreviations) is developing a series of courses for crop advisors in the agricultural US Midwest. Finally, CZO investigators routinely write opeds and produce videos for distribution to media audiences and use in pre-college classrooms. For example, the Southern Sierra CZO is a contributor to the "Sustainable California" web TV channel that was launched with other collaborators. CZOs and the national CZO office are active in social media.

Eighth, CZOs act as incubators that grow innovative teaching and mentor junior scientists who readily work across multiple disciplines. As shown in Table 1, 39 postdoctoral scholars worked at CZOs in 2015 along with 106 undergraduate and 186 graduate students. As more and more institutions in the United States have advertised positions that mention CZ science, these CZO students have moved easily into university department faculties where they are changing the research and education environment. Likewise, the recently completed InTeGrate project, Introduction to Critical Zone Science, is a one-semester undergraduate curriculum with lecture slides, online resources, and data drawn from the CZOs. This innovative new course uses the $\mathrm{CZ}$ as a unifying approach to teach complex Earth and environmental sciences (White et al., 2017). Many other teaching and training 
workshops have also been presented by the CZOs. For example, a Modeling Institute was presented in 2016 on the Dhara model (Le and Kumar, 2017, Woo and Kumar, 2017) and a training workshop was presented on the Role of Runoff and Erosion on Soil Carbon Stocks: From Soilscapes to Landscapes in collaboration with CUAHSI.

Ninth, CZOs act as an impetus for discoveries and emergent hypotheses that can only result from systematic and multidisciplinary observations across multiple CZ environments. Some of these hypotheses are disciplinary while others cross disciplines. A full elucidation of hypotheses is beyond the scope of this paper and only a subset is shown in Table 4. Many have been published in collaborative papers (Rempe and Dietrich, 2014; Riebe et al., 2016; Li et al., 2017; Pelletier et al., 2017; Yan et al., 2017; Brantley et al., 2017a). Here we summarize three multidisciplinary discoveries that have large implications for the prediction of flow paths relevant to the largest supply of accessible and drinkable water available to humans - water contained in rock and regolith (Fetter, 2001; Banks et al., 2009). These discoveries have been made both by non-CZO scientists and scientists within a CZO. First, one geophysics group outside of a CZO discovered a distinct geometry at depth that is consistent with the influence of regional tectonic stress fields on patterns of fractures and weathering under hillslopes (St. Clair et al., 2015). The theoretical underpinning proposed for this so-called "bow tie-shaped" geometry has important implications for predicting flow paths of water in regolith a priori. CZOs also discovered significant water storage that is seasonally available in the vadose zone of weathered bedrock (Bales et al., 2011; Salve et al., 2012). This rock moisture, missing from land surface models, has significant implications for predicting climate. Finally, CZO workers have identified depth intervals in the subsurface at some sites that document mineralogical reactions and that roughly mimic the land surface topography albeit with lower relief (Brantley et al., 2013). Such reaction fronts inform researchers about subsurface flow paths (Brantley et al., 2017b). All of these ideas are being tested at other settings around the world.

\section{CZO measurements and models}

As mentioned above, common measurements are being made (Table 2) and models are being used across sites (Table 3). The measurements target the SWEGS fluxes - solute, water, energy, gas, and sediments - as they move through the CZ, as well as such features as the form and age of the landscape and ecosystems (Fig. 4). Some of the observations are more extensive than others: for example, hydrometeorology, soil moisture dynamics, and measurements of concentration and discharge in streams are the focus of ongoing efforts at every CZO.
The CZOs' datasets are maintained as publicly available (http://criticalzone.org/national/data/) and are intended to serve the research community beyond those involved in each CZO. The types of data commonly include sensor and sampler measurements showing the temporal response of different locations in the $\mathrm{CZ}$ to meteoric events, spatially resolved geophysical and geochemical measurements of $\mathrm{CZ}$ structure, and lidar measurements of vegetation and bare earth topography, among others. The CZOs coordinate with each other to ensure that measurements are comparable across sites (i.e., the "common measurements" effort). Likewise, efforts are ongoing so that the posted datasets can be used easily by others to make cross-site comparisons and conduct cross-site studies.

The duration of time for individual datasets varies across the network. Generally, the time series datasets (sensor and sampler arrays, eddy covariance, hydrometeorology, vadose zone and saturated zone aqueous chemistry, etc.) have durations that are roughly equivalent to the age of the CZO sites, determined by the initiation of NSF funding. One caveat is that CZOs have often added new study locations that were not among the original set, affecting the time interval of data that is available at each location. In other cases, measurement series may have been terminated as new measurements were brought online.

Three sites (SS CZO, BC CZO, and SSH CZO) have been in operation since 2007 , and thus their longer-term observational datasets extend roughly over that duration. Three other sites (CJ CZO, LQ CZO, and CR CZO) that began operating 2 years later have measurements dating to 2009 . Four newer sites (IML CZO, CH CZO, RC CZO, and ER CZO) have datasets dating to 2013. One observatory (CR CZO) ceased functioning as a CZO in 2014. Therefore, at present, continuous time series datasets range in duration from ca. 4 to 10 years. In addition, however, several of the CZOs are located at sites that provide longer datasets through previous measurement programs (for example, the extremely long datasets available at the Reynolds Creek CZO). The nature of datasets duration is thus somewhat complex and varies depending upon data type and site, but the generalized intent is to enable the assessment of interannual variation over decades. The datasets are starting to drive extrapolations from the individual study sites to regional and continental scales. The duration of datasets also depends upon the residence times and mixing times of the various measured entities (Fig. 4).To integrate the measurements at different sites and to extrapolate forward and backward in time requires process-based modeling. As the common observational data accumulate, CZOs have been both developing new models and pursuing data comparisons with established models (Table 3). Currently, the initial CZ modeling efforts may be characterized into four groups as discussed below (Table 3 ).

The first includes the modification and coupling of existing codes to link various $\mathrm{CZ}$ processes (e.g., land-atmosphere exchange, saturated-unsaturated zone hydrology, biogeo- 


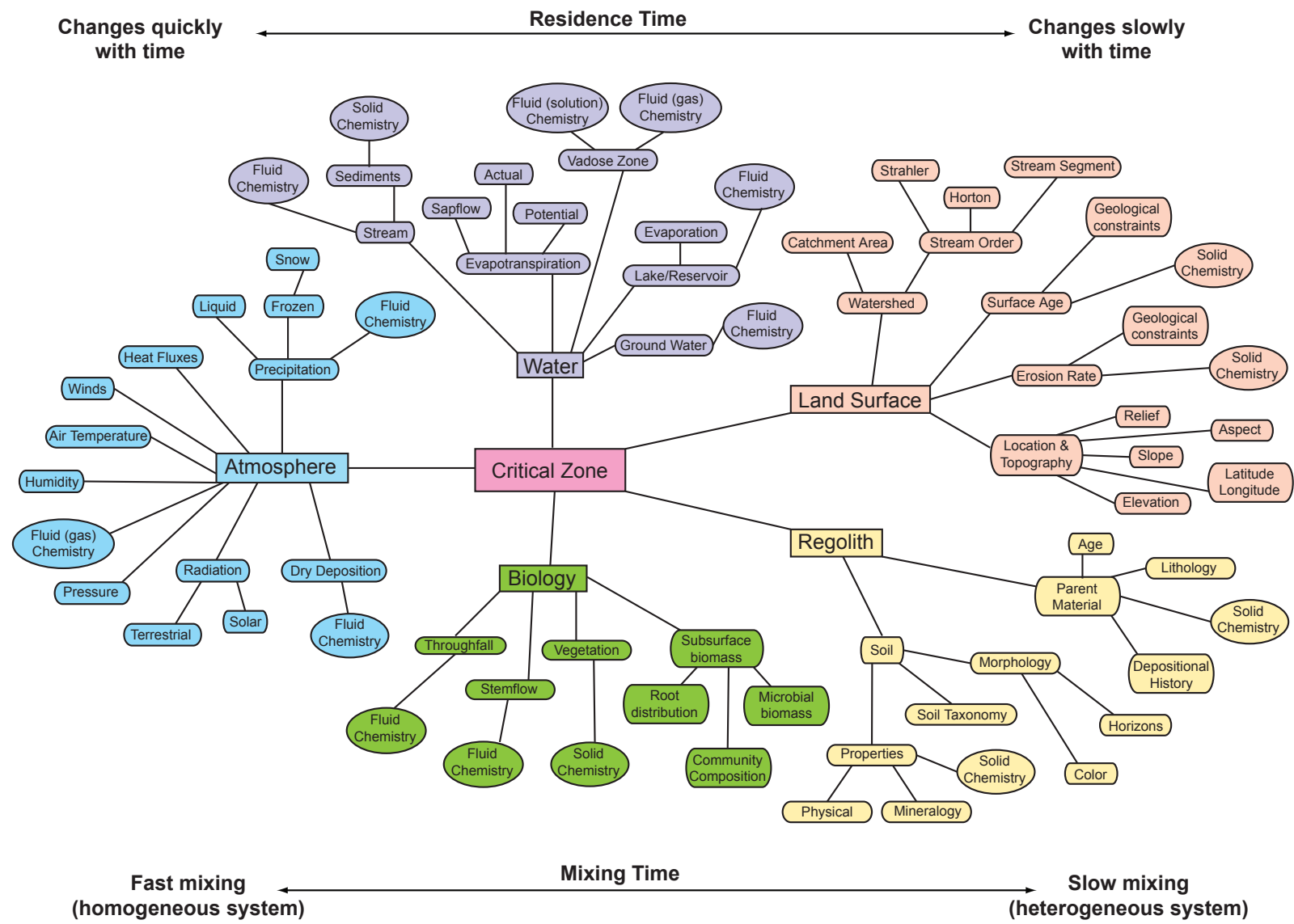

Figure 4. A schematic diagram showing some of the major entities that can be measured as part of the critical zone. The colors code entries related to the atmosphere (aqua), water (indigo), land surface features (beige), regolith (yellow), and biota (green). As shown by arrows, the entities are organized on the diagram from short to long residence times (left to right, respectively), and these correlate with generally fast to slow mixing times, respectively. Reproduced with permission from Niu et al. (2014).

chemistry, ecology) that are typically segregated in distinct models, but whose coupling is being revealed through $\mathrm{CZ}$ scientific measurements. The second includes identifying and filling critical gaps or knowledge of new processes such as hyporheic exchange, weathering, etc. The third includes development of a new generation of models that takes advantage of emerging streams of high-resolution data such as airborne- and unmanned-aerial-vehicle-based lidar and hyperspectral data. The fourth includes coupling between fast and slow processes across many timescales. Slow processes provide the template for the fast response variable, while the accumulative effect of the latter results in the evolution of the former. Both mathematical frameworks and data to support such modeling are still in their infancy.

\section{Emergent network-level concepts}

A central challenge of $\mathrm{CZ}$ science is the need to generalize from the place-based studies at observatories to principlebased understanding across the network or across the globe.
One way to do this (perhaps the only way) is with models. Dialogue is ongoing as to whether the $\mathrm{CZ}$ community will be best served through a single modeling framework or a library of existing models that allows more targeted exploration. Place-based studies can demand very specific investigations that are highly tuned to the biogeomorphic setting of a specific location, but that provide little deeper understanding. In contrast, a model that is broadly applicable may simplify the representation of a given site so much that the model results in reduced accuracy of prediction. Therefore, both the advancement of $\mathrm{CZ}$ science and $\mathrm{CZ}$ modeling will likely progress in an intertwined manner.

One way to further the evolution from place-based to principle-based understanding is to drive the development of fundamental understanding at a network level, rather than the level of a single observatory. In fact, since initiation of the CZO effort in 2007, three general, overarching concepts have emerged at the network level. Each of these describes deeper process- and principle-based understanding as summarized below. 
First, we have observed that differences in natural and anthropogenic inputs at Earth's surface translate into differences in water, regolith structure, minerals, and biotic activity at depth, and we are starting to detect how these deep properties also impact the biota, climate, and CZ services (e.g., Richter and Billings, 2015; Sullivan et al., 2016; Richardson and Kumar, 2017; Chorover et al., 2011).

Second, we have observed how the deep surface of the CZ varies across landscapes. Under hills, imaging has revealed locally consistent patterns of subsurface $\mathrm{CZ}$ structure that can relate depth, fracture density, porosity, and weathering (e.g., Befus et al., 2011; Brantley et al., 2013; Orlando et al., 2015; St. Clair et al., 2015).

Third, we now have mechanistic models that provide quantitative predictions of the spatial structure of the deep surface relative to the ground surface topography (e.g., Lebedeva and Brantley, 2013; Rempe and Dietrich, 2014; Rasmussen et al., 2015; Riebe et al., 2016). These three broad generalizations have been informed by up to 10 years of work at multiple $\mathrm{CZOs}$ as well as work by the greater $\mathrm{CZ}$ science community (Banwart et al., 2011).

In addition to the emergence of these network-level science concepts, an important link has emerged between the $\mathrm{CZ}$ and the concept of "ecosystem services". This concept emphasizes how biodiversity, ecological processes, and spatial patterns in the near-surface environment provide services to society (MEA, 2005). As discussed by CZO network scientists (Field et al., 2015, 2016), CZ science demonstrates the contribution of the deeper $\mathrm{CZ}$ to ecosystem "provisioning" and elucidates the longer timescales of $\mathrm{CZ}$ evolution, leading to the idea of "critical zone services". Through this lens, services such as water quality regulation, soil development, and carbon stabilization are seen as tightly dependent on $\mathrm{CZ}$ function, evolution, and architecture. The valuation of CZ services offers an approach for the assessment of human impact that takes into consideration both the short- and long-timescale processes (Richardson and Kumar, 2017). Indeed, the $\mathrm{CZ}$ is the ideal context for integrating deep subsurface and long-timescale perspectives from geosciences into the otherwise biocentric conceptualization of ecosystem services. Doing so remains an emphasis of CZO network activities.

\section{Strengths and weaknesses of the current CZO network}

The current CZO network as constituted in the United States and abroad has many strengths. Students are trained to cross disciplines within their work, and they graduate with convergent expertise in the new field of $\mathrm{CZ}$ science. $\mathrm{CZ}$ science harmonizes vocabulary and conceptual understanding across disciplines and sets a research agenda and an integrated approach. Postdoctoral scholars learn from observatory personnel that derive from many disciplines. Such scientists now communicate as effectively about sap flow in trees as about seasonal variations in groundwater flow. Collaborations are constantly developing and allowing scientists to see problems with different perspectives. Ideas about regolith formation (Riebe et al., 2016), snow hydrology (Harpold et al., 2014; Tennant et al., 2017), microbial diversity (Fierer et al., 2003), trees (Brantley et al., 2017a), and many other topics are growing across the network. We have produced enormous datasets (http://criticalzone.org/national/data/datasets/). We no longer treat parts of the $\mathrm{CZ}$ as isolated components or black boxes: instead, we incorporate more specificity and understanding when we describe the integrated system. We are finding innovative ways to communicate the $\mathrm{CZ}$ concept to the public. We have stimulated and promoted development of CZOs worldwide.

Although there have been many successes, we also observe weaknesses. Since each observatory is individually funded based on the merits of its targeted science, there is competition for allocation of resources to address common measurements versus site-specific activities. This results in a less-than-optimal identification of emergent network-scale outcomes. Of course, individual site-specific outcomes can have implications and impacts that are just as important as network-scale outcomes. Thus, we need to find mechanisms to foster all such approaches while acknowledging limitations in resources. Further, given how new $\mathrm{CZ}$ science is, insights that cut across multiple disciplines are only just beginning to emerge. We still have occasional difficulty communicating these ideas in a simple fashion. One specific example of a need for cross-disciplinary ideas and communication arises from the fact that the CZO network in the United States never emphasized social science. Thus, hypotheses have yet to emerge that target social science aspects of the $\mathrm{CZ}$. Another challenge, and perhaps our biggest, is maintaining the integrity of an interdisciplinary suite of measurements in a common database and managing site data (Fig. 4) in ways that invite other researchers to find and use the datasets (Hinckley et al., 2016). The need for better data management is especially important given the many new data-driven approaches that are arising within environmental science (Bui, 2016).

These considerations in the context of the overview in this paper lead to a basic question: how might we design the best mechanism to advance $\mathrm{CZ}$ science? We point to four specific challenges, posed here as questions, that loom large in designing the future network. First, what is the best approach to developing broadly applicable principles from observatorybased investigations? Second, how do we link appropriately with other programs in the United States and worldwide to develop a set of representative sites across the large number of possible environmental gradients to advance a broad understanding of CZ science? Third, how should we balance the roles of CZOs in developing long-term observational records versus shifting measurement strategies to advance and test new hypotheses? Fourth, what funding and 
management models would enable increased involvement of $\mathrm{CZ}$ scientists who are not yet part of core CZO teams? These four issues are addressed in the next section in which we propose a new model for the future of the network.

\section{The future network}

Mechanisms that have been successful in stimulating deeper understanding of the environment were described above. These strategies can be summarized as (i) small investigator projects targeting parts of the $\mathrm{CZ}$, (ii) campaign-style multiinvestigator projects targeting multiple sites, (iii) centerbased efforts, and (iv) observatories. Looking into the future, all are needed.

For example, individual grants (example (i) from above) can test sharply focused hypotheses that may lead to important discoveries about individual entities or processes. This kind of research, typically supported by a core grant from within a specific discipline (e.g., hydrology) sustains both the discipline and advances $\mathrm{CZ}$ science. The last decades of research have clearly shown that some advances come from single-investigator research.

Mechanism (ii), campaign-style research, has the advantage of exploring $\mathrm{CZ}$ questions over a range of conditions (Larsen et al., 2015). Such campaigns often focus on material properties or process dynamics. Campaign-style research can focus many different one-time measurements, or measurements across a larger spatial scale, than CZOs can routinely accomplish. Campaigns typically incorporate small teams of researchers.

Establishment of centers (approach iii) is another important means to guide and test field data collection and to probe for deeper understanding by fostering communication and collaboration among many researchers. However, the CZO approach (iv) is the only approach that forces diverse researchers to tackle fundamental questions at a single location while also performing the nine important roles described above. In particular, only observatories provide the long-term data and the diverse co-located observations from all disciplines that we need to understand the CZ. By working together with centers, only place-based observatories can knit together disparate views by acting as gathering points for scientists from all disciplines with all their skills, instruments, and models.

However, because the CZ is highly heterogeneous, the network must be designed to promote the emergence of informative ideas that supersedes this heterogeneity. In other words, CZOs must collaborate to engender network-level insights. Given this need, one approach may be for the community to identify a broad common question for the future and then to design the future network to target this overall question. One proposed example for the next decade of CZO research is the following question of central importance:
How can we increase our understanding of surface and subsurface landscapes and fluxes as we face climate, land use, and other anthropogenic changes in the future?

With such a question, the entire CZO network could test sub-questions and sub-hypotheses together, but with experiments at different sites with different characteristics.

Even if the CZOs target this question together, some adjustments to the current topology of the CZO network should be evaluated and updated so as to promote the emergence of network-level ideas. Indeed, many other topologies can be imagined (Fig. 5). Many scientists have similarly considered aspects of what is needed for environmental networks (Leopold, 1962). For example, one topology might be to choose new observatories to fill in gaps among the current nine CZOs, as shown schematically in the diagram. Another model might be to continue the current nine CZOs as the future network in order to sustain both their unique observational records and the theoretical advances these advances enable. Another model might be to choose nine (or some other optimized number) completely new CZOs, i.e., treating the country as a blank slate. Another model might be to complete a careful analysis of the current CZOs in the context of LTER sites and LTAR sites and then to extend the network appropriately. NEON should also be part of this leveraging, as it becomes operational nationwide. A fifth model might be to establish various "hub" locations and then choose smaller sites along environmental gradients extending out from the hub. Finally, many CZOs might be funded for research along with smaller satellite sites that extend from the central CZO.

In thinking about the future network topology, we emphasize the need to find solutions to the four problems stated as questions at the end of the last section: (1) the need to advance principle-based understanding from observatories; (2) the need to coordinate with other US programs and CZOs worldwide to sample a wide range of CZ conditions; (3) the need for balance between measurements for hypothesis testing and common, core measurements as network infrastructure; and (4) the desire to incorporate an even broader community of researchers into the CZO program.

The best topology to address these issues is a design like the hub-and-spoke model but with multiple hubs and a high degree of scientific coordination with the other networks noted above. In addition, instead of spokes, i.e., lines of satellite sites that extend geographically out from the hub, we prefer to call these "campaigns", noting that in some cases these satellites might indeed be spokes, but in other cases they might be located in vastly disparate locations. This model would answer the need for long-term measurements (at carefully chosen hubs), the need for short-term targeted measurements at specific locations both within the United States and abroad (carefully chosen campaign sites), and the need for new mechanisms to engage more investigators (funding to bring in scientists from outside the hub network). This long- 


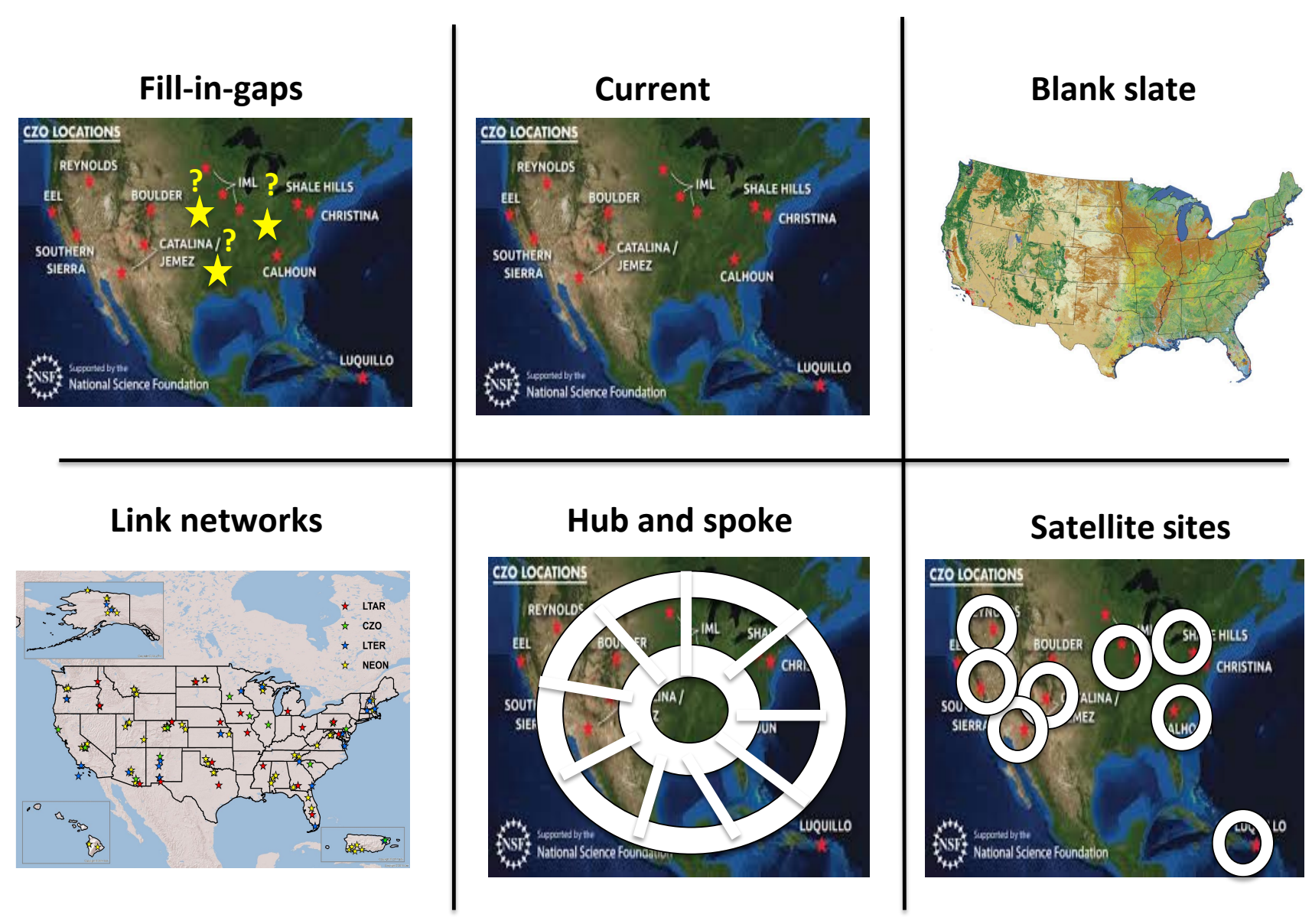

Figure 5. Conformations of a future CZO network discussed in the text. The most effective topology is likely to be a combination of the observatory framework with smaller campaign-style science as discussed in the text, i.e., a hubs-and-campaign strategy. LTAR - LongTerm Agroecosystem Research; CZO - Critical Zone Observatory; LTER - Long-Term Ecological Research; NEON - National Ecological Observatory Network.

term hub and short-term campaign emphasis has been promoted in the literature by researchers both inside and outside the current CZO funding framework (Banwart et al., 2012; Larsen et al., 2015). Fundamentally, the argument for the hub-and-campaign approach is that the two methods benefit from each other. Specifically, the hub provides the unique opportunity to dig deep into understanding mechanisms and process dynamics, whereas the campaign approach provides an opportunity to test the generality of specific findings, ideas, or theories across some relevant gradient, e.g., in climate, land use, or tectonic activity, while bringing in outside researchers.

Specifically, we propose a hubs-and-campaign network that would consist of several CZOs as hubs that would provide the infrastructure for common measurements - and would be stimuli for ephemeral campaigns funded for shorter periods with more constrained purposes that incorporate nonCZO personnel. The hubs would perform all nine of the CZO roles listed above and would receive stable funding. In contrast, the campaigns would be funded in efforts for shorter time periods to test specific hypotheses or ideas. In this way, the network would be able to change appropriately with time and cover more environments, would provide both infrastructure and hypothesis testing, and could be nimble and inviting for more groups to participate.

It makes sense for the hubs to be located in settings of broad interest from a scientific and societal point of view. For example, an urban CZO could be considered. Alternately (or in addition), the hubs could be located to test specific hypotheses about $\mathrm{CZ}$ structure and controls across gradients of attributes such as climate or tectonic activity or disturbance. Hubs, chosen for their strategic and scientific importance, would presumably also be chosen in recognition of the needs of human resources for education and outreach, and of the need for both applied and curiosity-driven science. The potential use of hubs as attractors for students and scientists and platforms for increasing diversity in the Earth and environmental sciences would need to be stressed. 
10

\section{Conclusions}

We now recognize the critical zone as an entity composed of co-evolving systems that create the structured dynamic skin of the Earth. We are seeing the first maps of this structure as they emerge and we are discovering how the structure influences water resources and hydrologic processes, vegetation, ecosystems, erosion, biogeochemical processes, and even regional climate. Surface and deep processes are connected. A first set of testable models has emerged and now points to specific measurement programs. But this is only the beginning. While progress has been made, the central questions remain: what controls the critical zone properties and processes, how does the critical zone respond to climate and land use change, and how can we use our advancing understanding to benefit societal needs? These fundamental questions will require a sustained research commitment. The critical zone is a frontier area of science in which only the first observations have been obtained. New methods, instrumentation, and theory are needed to continue to grow convergent understanding.

Future research in critical zone science will be best advanced through a combination of distributed long-term observatories strongly coupled with focused, campaign-style investigations. These campaigns would target new sites that might radiate from the central hub observatory to test specific hypotheses and theories across controlling gradients. The observatories would focus on the necessary long-term monitoring to reveal mechanisms and dynamics. The field campaigns would collect data over shorter periods.

The decision by the US National Science Foundation to support a network of critical zone observatories since 2007 has laid the foundation for a new discipline of critical zone science that has driven the convergence of individual scientific disciplines. Former graduate students supported at the CZOs are now taking up faculty posts and rapidly introducing new courses that span the many disciplines needed to reveal critical zone workings. The next generation is in the making. Findings from the CZOs are being absorbed by agencies and put to practice. The power of the critical zone concept has spread across the globe and stimulated the building of numerous critical zone observatories. We are seeing just the beginning and it is time for the next chapter.

Data availability. No data sets were used in this article.

Competing interests. The authors declare that they have no conflict of interest but nine are principal investigators of Critical Zone Observatories (S. L. Brantley, W. H. McDowell, W. E. Dietrich, P. Kumar, S. P. Anderson, J. Chorover, K. A. Lohse, R. C. Bales, and D. deB. Richter), and one (T. White) is the program coordinator for the national $\mathrm{CZO}$ network.
Acknowledgements. We acknowledge the help of Sarah Sharkey (funded by the CZO Science Across Virtual Institutes Project), Jennifer Williams, Tracy Bernier, and Debra Lambert, and funding from NSF grants EAR 13-31726 to Susan L. Brantley, EAR 13-31906 to Praveen Kumar, EAR 13-31872 to Kathleen A. Lohse, EAR 13-31846 to Daniel deB. Richter, EAR 13-31408 to Jon Chorover, EAR13-31828 to Suzanne Anderson, EAR 14-45246 to Timothy S. White, EAR 13-31841 to William H. McDowell, and EAR13-31940 to William E. Dietrich. The paper benefitted from reviews by Jon Tunnicliffe and the anonymous reviewer, and comments from Kevin Bishop, Paul Schroeder, and Elisabeth Bui, and editorial handling by Jens Turowski.

Edited by: Jens Turowski

Reviewed by: Jon Tunnicliffe and one anonymous referee

\section{References}

Anderson, S. P., Blum, J., Brantley, S. L., Chadwick, O., Chorover, J., Derry, L. A., Drever, J. I., Hering, J. G., Kirchner, J. W., Kump, L. R., Richter, D., and White, A. F.: Proposed initiative would study Earth's weathering engine, EOS, Transactions of the American Geophysical Union, 85, 265-269, https://doi.org/10.1029/2004EO280001, 2004.

Anderson, S. P., Bales, R. C., and Duffy, C. J.: Critical Zone Observatories: Building a network to advance interdisciplinary study of Earth surface processes, Mineral. Mag., 72, 7-10, https://doi.org/10.1180/minmag.2008.072.1.7, 2008.

Anderson, S. W., Anderson, S. P., and Anderson, R. S.: Exhumation by debris flows in the 2013 Colorado Front Range storm, Geology, 43, 391-394, 2015.

Bales, R. C., Hopmans, J. W., O'Geen, A. T., Meadows, M., Hartsough, P. C., Kirchner, P., Hunsaker, C. T., and Beaudette, D.: Soil moisture response to snowmelt and rainfall in a Sierra Nevada mixed-conifer forest, Vadose Zone J., 10, 786-799, 2011.

Banks, E. W., Simmons, C. T., Love, A. J., Cranswick, R., Werner, A. D., Bestland, E. A., Wood, M., and Wilson, T.: Fractured bedrock and saprolite hydrogeologic controls on groundwater/surface-water interaction: A conceptual model (Australia), Hydrogeol. J., 17, 1969-1989, 2009.

Banwart, S., Bernasconi, S. M., Bloem, J., Blum, W., Brandao, M., Brantley, S. L., Chabaux, F., Duffy, C. J., Kram, P., Lair, G., Lundin, L., Nikolaidis, N., Novak, M., Panagos, P., Ragnarsdottir, K. V., Reynolds, B., Rousseva, S., de Ruiter, P., van Gaans, P., van Riemsdijk, W., White, T. S., and Zhang, B.: Soil processes and functions in Critical Zone Observatories: Hypotheses and experimental design, Vadose Zone J. Special Section: Critical Zone Observatories, 10, 974-987, 2011.

Banwart, S., Menon, M., Bernasconi, S. M., Bloem, J., Blum, W. E. H., de Souza, D. M., Davidsdotir, B., Duffy, C., Lair, G. J., Kram, P., Lamacova, A., Lundin, L., Nikolaidis, N. P., Novak, M., Panagos, P., Ragnarsdottir, K. V., Reynolds, B., Robinson, D., Rousseva, S., de Ruiter, P., van Gaans, P., Weng, L., White, T., and Zhang, B.: Soil processes and functions across an international network of Critical Zone Observatories: Introduction to experimental methods and initial results, C. R. Geosci., 344, 758-772, 2012. 
Befus, K. M., Sheehan, A. F., Leopold, M., Anderson, S. P., and Anderson, R. S.: Seismic constraints on critical zone architecture, Boulder Creek Watershed, Colorado, Vadose Zone J., 10, 915-927, https://doi.org/10.2136/vzj2010.0108, 2011.

Berner, R. A.: Jacques-Joseph Ebelmen, the founder of earth system science, C. R. Geosci., 344, 544-548, 2012.

Bormann, F. H. and Likens, G. E.: Nutrient Cycling, Science, 155, 424-429, 1967.

Bormann, F. H. and Likens, G. E.: Pattern and process in a forested ecosystem: disturbance, development, and the steady state based on the Hubbard Brook ecosystem study, Springer-Verlag, New York, 1979.

Brantley, S. L., White, T. S., White, A. F., Sparks, D., Richter, D., Pregitzer, K., Derry, L., Chorover, J., Chadwick, O., April, R., Anderson, S., and Amundson, R.: Frontiers in Exploration of the Critical Zone: Report of a workshop sponsored by the NSF Newark, DE, 30 pp., 2006.

Brantley, S. L., Holleran, M. E., Jin, L., and Bazilevskaya, E.: Probing deep weathering in the Shale Hills Critical Zone Observatory, Pennsylvania (U.S.A.): the hypothesis of nested chemical reaction fronts in the subsurface, Earth Surface Processes and Landforms, https://doi.org/10.1002/esp.3415, 2013.

Brantley, S. L., DiBiase, R. A., Russo, T. A., Shi, Y., Lin, H., Davis, K. J., Kaye, M., Hill, L., Kaye, J., Eissenstat, D. M., Hoagland, B., Dere, A. L., Neal, A. L., Brubaker, K. M., and Arthur, D. K.: Designing a suite of measurements to understand the critical zone, Earth Surf. Dynam., 4, 211-235, https://doi.org/10.5194/esurf-4-211-2016, 2016.

Brantley, S. L., Eissenstat, D. M., Marshall, J. A., Godsey, S. E., Balogh-Brunstad, Z., Karwan, D. L., Papuga, S. A., Roering, J., Dawson, T. E., Evaristo, J., Chadwick, O., McDonnell, J. J., and Weathers, K. C.: Reviews and syntheses: on the roles trees play in building and plumbing the critical zone, Biogeosciences, 14, 5115-5142, https://doi.org/10.5194/bg-14-5115-2017, 2017a.

Brantley, S. L., Lebedeva, M. I., Balashov, V. N., Singha, K., Sullivan, P. L., and Stinchcomb, G.: Toward a conceptual model relating chemical reaction fronts to water flow paths in hills, Geomorphology, 277, 100-117, https://doi.org/10.1016/j.geomorph.2016.09.027, 2017b.

Bui, E. N.: Data-driven Critical Zone science: A new paradigm, Sci. Total Environ., 568, 587-593, 2016.

Callahan, J. T.: Long-term ecological research, BioScience, 34, 363-367, 1984.

Coughlan, M. R., Nelson, D. R., Lonneman, M., and Block, A. E.: Historical land use dynamics in the highly degraded landscape of the Calhoun Critical Zone Observatory, Calhoun CZO 2017 Summer Science Meeting, Union, SC, 2017.

CFIR CSEPP: Facilitating interdisciplinary science, Committee Facilitating Interdisciplinary Research and Committee on Science Engineering and Public Policy, The National Academies Press, Washington, D.C. , 2005.

Chen, X., Kumar, M., Mau, Y., and Richter, D. d.: Impact of gully incision on hillslope hydrology, Water Resour. Res., 2017, in press.

Chorover, J., Kretzschmar, R., Garcia-Pichel, F., and Sparks, D. L.: Soil biogeochemical processes within the Critical Zone, Elements, 3, 321-326, 2007.

Chorover, J., Troch, P. A., Rasmussen, C., Brooks, P. D., Pelletier, J. D., Breshears, D. D., Huxman, T. E., Kurc, S. A., Lohse, K.
A., McIntosh, J. C., Meixner, T., Schaap, M. G., Litvak, M. E., Perdrial, J., Harpold, A., and Durcik, M.: How water, carbon, and energy drive landscape evolution and surface water dynamics: The Jemez River Basin - Santa Catalina Mountains Critical Zone Observatory, Vadose Zone J., Special Issue on the Critical Zone, 10, 884-889, https://doi.org/10.2136/vzj2010.0132, 2011.

Chorover, J., Derry, L. A., and McDowell, W. H.: Concentrationdischarge relations in the critical zone: Implications for resolving critical zone structure, function, and evolution, Water Resour. Res., https://doi.org/10.1002/2017WR021111, 2017.

Cobb, E. D. and Biesecker, J. E.: The National Hydrologic BenchMark Network, U.S. Geological Survey Circular 460-D, U.S. Department of the Interior, Geological Survey, Washington, D.C., 1971.

Committee on New Research Opportunities in the Earth Sciences at the National Science Foundation: New research opportunities in Earth Sciences, National Research Council, National Academies Press, Washington, D.C., 2012.

Dialynas, Y. G., Bastola, S., Bras, R. L., Billings, S. A., Richter, D. deB., and Markewitz, D.: A Coupled Spatially Explicit Modelling Approach to Assess the Influence of Soil Erosion and Deposition on the Redistribution of Soil Organic Carbon at the Watershed Scale, 2nd Annual Southeastern Biogeochemistry Symposium, Atlanta, GA, 28-29 March, 2015.

Dodds, W. K., Robinson, C. T., Gaiser, E. E., Hansen, G. J. A., Powell, H., Smith, J. M., Morse, N. B., Johnson, S. L., Gregory, S. V., Bell, T., Kratz, T. K., McDowell, W. H.: Surprises and insights from long-term aquatic data sets and experiments, BioScience, 62, 709-721, https://doi.org/10.1525/bio.2012.62.8.4, 2012.

Druhan, J. L., Fernandez, N. M., Wang, J., Dietrich, W. E., and Rempe, D.: Seasonal shifts in the solute ion ratios of vadose zone rock moisture from the EEL River Critical Zone Observatory, Acta Geochimica, https://doi.org/10.1007/s11631-0170169-z, 2017.

Duffy, C., Shi, Y., Davis, K., Slingerland, R., Li, L., Sullivan, P. L., Godderis, Y., and Brantley, S. L.: Designing a suite of models to explore critical zone function, Proced. Earth Plan. Sc., 10, 7-15, https://doi.org/10.1016/j.proeps.2014.08.003, 2014.

Easterling, W. E.: Climate change and the adequacy of food and timber in the 21st century, P. Natl. Acad. Sci. USA, 104, 1967919679, 2007.

Ebel, B. A., Rengers, F. K., and Tucker, G. E.: Aspect-dependent soil saturation and insight into debris-flow initiation during extreme rainfall in the Colorado Front Range, Geology, 43, 659662, 2015.

Enslin, C., Godsey, S., Marks, D. G., Kormos, P. R., Seyfried, M. S., Link, T., and Mcnamara, J.: Data set: A modeling dataset that spans the rain - snow transition zone: Johnston Draw catchment, Reynolds Creek Experimental Watershed, Idaho, USA, Ag Data Commons, USDA National Agricultural Library, https://doi.org/10.15482/USDA.ADC/1258769, 2016.

Fetter, C. W.: Applied Hydrogeology, Prentice Hall, Upper Saddle River, New Jersey, USA, 2001.

Field, J. P., Breshears, D. D., Law, D. J., Villegas, J. C., López-Hoffman, L., Brooks, P. D., Chorover, J., BarronGafford, G. A., Gallery, R. E., Litvak, M. E., Lybrand, R. A., McIntosh, J. C., Meixner, T., Niu, G-Y., Papuga, S. A., Pelletier, J. D., Rasmussen, C. R., and Troch, P. A.: Critical Zone Services: Expanding Context, Constraints, and 
Currency beyond Ecosystem Services, Vadose Zone J., 14, https://doi.org/10.2136/vzj2014.10.0142, 2015.

Field, J. P., Breshears, D. D., Law, D. J., Villegas, J. C., LopezHoffman, L., Brooks, P. D., Chorover, J., and Pelletier, J. D.: Understanding Ecosystem Services from a Geosciences Perspective, Eos, Transactions American Geophysical Union, 97, 10-11, https://doi.org/10.1029/2016EO043591, 2016.

Fierer, N., Schimel, J. P., and Holden, P. A.: Variations in microbial community composition through two soil depth profiles, Soil Biol. Biochem., 35, 167-176, 2003.

Forbes, S. T.: The lake as a microcosm, Bulletin Peoria (Illinois) Scientific Association, 77-87, 1887.

Foster, M. A. and Anderson, R. S.: Assessing the effect of a major storm on $10 \mathrm{Be}$ concentrations and inferred basin-averaged denudation rates, Quat. Geochronol., 34, 58-68, 2016.

Giardino, J. R. and Houser, C.: Principles and Dynamics of the Critical Zone, Elsevier Press, 2015.

Gochis, D., Schumacher, R., Friedrich, K., Doesken, N., Kelsch, M., Sun, J., Ikeda, K., Lindsey, D., Wood, A., Dolan, B., Matrosov, S., Newman, A., Mahoney, K., Rutledge, S., Johnson, R., Kucera, P., Kennedy, P., Sempere-Torres, D., Steiner, M., Roberts, R., Wilson, J., Yu, W., Chandrasekar, V., Rasmussen, R., Anderson, A., and Brown, B.: The Great Colorado Flood of September 2013, B. Am. Meteorol. Soc., 96, 1461-1487, https://doi.org/10.1175/BAMS-D-13-00241.1, 2015.

Godsey, S. E., Kirchner, J. W., and Clow, D. W.: Concentrationdischarge relationships reflect chemostatic characteristics of US catchments, Hydrol. Process., 23, 1844-1864, https://doi.org/10.1002/hyp.7315, 2009.

Golz, H. L., Marinelli, R., and Taylor, P. R.: Reflections on LTER from NSF Program Director's Perspectives, in: Long-Term Ecological Research, Changing the Nature of Scientists, edited by: Willig, M. R. and Walker, L. R., Oxford University Press, 2016.

Goulden, M. L. and Bales, R. C.: Mountain runoff vulnerability to increased evapotranspiration with vegetation expansion, P. Natl. Acad. Sci. USA, 111, 14071-14075, 2014.

Goulden, M. L., Bales, R. C., Kelly, A. E., Meadows, M., and Winston, G. C.: Evapotranspiration along an elevation gradient in California's Sierra Nevada, J. Geophys. Res.-Biogeo., 117, G03028, https://doi.org/10.1029/2012JG002027, 2012.

Harpold, A. A., Biederman, J. A., Condon, K., Merino, M., Korgaonkar, Y., Nan, T., Sloat, L. L., Ross, M., and Brooks, P. D.: Changes in snow accumulation and ablation following the Las Conchas Forest Fire, New Mexico, USA, Ecohydrology, 7, 440$452,2014$.

Hinckley, E.-L., Anderson, S. P., Baron, J. S., Blanken, P. D., Bonan, G. B., Bowman, W. D., Elmendorf, S. C., Fierer, N., Fox, A. M., Goodman, K. J., Jones, K. D., Lombardozzi, D. L., Lunch, C. K., Neff, J. C., Sanclements, M. D., Suding, K. N., and Wieder, W. R.: Optimizing available network resources to address questions in environmental biogeochemistry, BioScience, 66, 317326, https://doi.org/10.1093/biosci/biw005, 2016.

Holbrook, W. S., Riebe, C. S., Elwaseif, M., Hayes, J. L., BaslerReeder, K., Harry, D. L., Malazian, A., Dosseto, A., Hartsough, P. C., and Hopmans, J. W.: Geophysical constraints on deep weathering and water storage potential in the Southern Sierra Critical Zone Observatory, Earth Surf. Proc. Land., 39, 366-380, https://doi.org/10.1002/esp.3502, 2014.
Horsbaugh, J. S., Tarboton, D. G., Maidment, D. R., and Zaslavsky, I.: A relational model for environmental and water resources data, Water Resour. Res., 44, W05406, https://doi.org/10.1029/2007WR006392, 2008.

Hynek, S., Comas, X., and Brantley, S. L.: The effect of fractures on weathering of igneous and volcaniclastic sedimentary rocks in the Puerto Rican tropical rain forest, Proced. Earth Plan. Sc., 17, 972-975, https://doi.org/10.1016/j.proeps.2017.01.001, 2017.

Hynes, H. B. N.: The stream and its valley, Verhandlungen der Internationalen Vereinigung für Theoretische und Angewandte Limnologie, 19, 1-15, 1975.

Kerkez, B., Glaser, S. D., Bales, R. C., and Meadows, M. W.: Design and performance of a wireless sensor network for catchmentscale snow and soil moisture measurements, Water Resour. Res., 48, W09515, 2012.

Kirchner, J. W.: A double paradox in catchment hydrology and geochemistry, Hydrol. Process., 17, 871-874, 2003.

Klein, T. I., Anderson, S. P., Murphy, S. F., Ross, M., Hammack, G., and Anderson, R. S.: High-intensity rain storm connects hillslopes to channels in a steep semi-arid catchment, AGU Chapman Conference on Extreme Climate Events on Aquatic Biogeochemical Cycles and Fluxes, San Juan, Puerto Rico, 2017.

Kormos, P. R., Marks, D. G., Seyfried, M. S., Havens, S. C., Hedrick, A., Lohse, K., Masarik, M., and Flores, A.: Data set: 31 years of spatially distributed air temperature, humidity, precipitation amount and precipitation phase from a mountain catchment in the rain-snow transition zone, Boise State University, Reynolds Creek Critical Zone Observatory, Boise, ID, https://doi.org/10.18122/B2B59V, 2016.

Larsen, L., Hajek, E., Maher, K., Paola, C., Merritts, D., Bralower, T., Montanez, I., Wing, S., Snyder, N., Hochella, M., Kump, L., and Person, M.: Taking the pulse of the Earth's surface systems, EOS, 96, https://doi.org/10.1029/2015EO040525, 2015.

Latour, B.: Some advantages of the notion of "Critical Zone" for geopolitics, Proced. Earth Plan. Sc., 10, 3-6, 2014.

Le, P. V. V. and Kumar, P.: Interaction between ecohydrologic dynamics and microtopographic variability under climate change, Water Resour. Res., 53, 8383-8403, https://doi.org/10.1002/2017WR020377, 2017.

Le, P. V. V., Kumar, P., Valocchi, A., and Dang, V. H.: GPUbased high-performance computing for surface - sub-surface conjunctive flow modeling, Environ. Modell. Softw., 73, 1-13, https://doi.org/10.1016/j.envsoft.2015.07.015, 2015.

Lebedeva, M. and Brantley, S. L.: Exploring geochemical controls on weathering and erosion of convex hillslopes: beyond the empirical regolith production function, Earth Surf. Proc. Land., 38, 1793-1807, https://doi.org/10.1002/esp.3424, 2013.

Leopold, L. B.: A National Network of Hydrologic Bench Marks, USGS Circular 460-B, U.S. Geological Survey, Department of the Interior, Washington D.C., 1962.

Li, L., Maher, K., Navarre-Sitchler, A., Druhan, J., Meile, C., Lawrence, C., Moore, J., Perdrial, J., Sullivan, P., Thompson, A., Jin, L. X., Bolton, E. W., Brantley, S. L., Dietrich, W. E., Mayer, K. U., Steefel, C. I., Valocchi, A., Zachara, J., Kocar, B., McIntosh, J., Tutolo, B. M., Kumar, M., Sonnenthal, E., Bao, C., and Beisman, J.: Expanding the role of reactive transport models in critical zone processes, Earth-Sci. Rev., 165, 280-301, 2017.

Loescher, H. W., Kelly, E. F., and Lea, R.: National Ecological Observatory Network: Beginnings, Programmatic and Sci- 
entific Challenges, and Ecological Forecasting, in: Terrestrial Ecosystem Research Infrastructures: Challenges and Opportunities, edited by: Chabbi, A. and Loescher, H. W., CRC Press, Boca Raton, FL, 2017.

Lugo, A. E., Swanson, F. J., and Gonzalez, O. R.: Long-term research at the USDA Forest Service's experimental forests and ranges, BioScience, 56, 39-48, 2006.

Mast, M. A.: Evaluation of stream chemistry trends in US Geological Survey reference watersheds, 1970-2010, Environ. Monit. Assess., 185, 9343-9359, 2013.

McHale, M. R., Siemion, J., Lawrence, G. B., and Mast, M. A.: Long-term Soil Monitoring at U.S. Geological Survey Reference Watersheds, U.S. Geological Survey Fact Sheet, Reston, VA, USA, 2 pp., https://doi.org/10.3133/fs20143002, 2014.

Millennium Ecosystem Assessment (MEA): Ecosystems and human well-being: Synthesis, Island Press, Washington, DC, 2005.

Millennium Ecosystem Assessment Board: Living Beyond our Means: Natural Assets and Human Well-Being, 2005.

Miller, M. P., Boyer, E. W., McKnight, D. M., Brown, M. G., Gabor, R. S., Hunsaker, C. T., Iavorivska, L., Inamdar, S., Johnson, D. W., Kaplan, L. A., Lin, H., McDowell, W. H., and Perdrial, J. N.: Variation of organic matter quantity and quality in streams at Critical Zone Observatory watersheds, Water Resour. Res., 52, 8202-8216, 2016.

Mobley, M. L., Lajtha, K., Kramer, M. G., Bacon, A. R., Heine, P. R., and Richter, D. deB.: Surficial gains and subsoil losses of soil carbon and nitrogen during secondary forest development, Global Change Biol., 21, 986-996, https://doi.org/10.1111/gcb.12715, 2015.

Murphy, S. F., McCleskey, R. B., and Writer, J. W.: Effects of flow regime on stream turbidity and suspended solids after wildfire, Colorado Front Range, IAHS Redbook, Proceedings of a conference held in Banff, 11-14 June 2012, Canada, 354, 51-58, 2012.

Navarre-Sitchler, A., Cole, D. R., Rother, G., Jin, L., Buss, H. L., and Brantley, S. L.: Porosity and surface area evolution during weathering of two igneous rocks, Geochim. Cosmochim. Ac., 109, 400-413, https://doi.org/10.1016/j.gca.2013.02.012, 2013.

Niu, G.-Y., Paniconi, C., Troch, P. A., Scott, R. L., Durcik, M., Zeng, X., Huxman, T., and Goodrich, D. C.: An integrated modelling framework of catchment-scale ecohydrological processes: 1. Model description and tests over an energy-limited watershed, Ecohydrology, 7, 427-439, https://doi.org/10.1002/eco.1362, 2014

Ohl, C. and Swinton, S. M.: Integrating Social Sciences into Long-Term Ecological Research, in: Long-Term Ecological Research: Between Theory and Application, edited by: Müller, F., Baessler, C., Schubert, H., Klotz, S., Springer, Dordrecht, 399410, https://doi.org/10.1007/978-90-481-8782-9_27, 2010.

Olyphant, J., Pelletier, J. D., and Johnson, R.: Topographic correlations with soil and regolith thickness from shallow-seismic refraction constraints across upland hillslopes in the Valles Caldera, New Mexico, Earth Surf. Proc. Land., 41, 1684-1696, 2016

Orlando, J., Comas, X., Hynek, S., Buss, H. L., and Brantley, S. L.: Architecture of the deep critical zone in the Rio Icacos watershed (Luquillo Critical Zone Observatory, Puerto Rico) inferred from drilling and ground penetrating radar (GPR), Earth Surf. Proc. Land., 41, 1826-1840, https://doi.org/10.1002/esp.3948, 2015.
Painter, T. H., Berisford, D. F., Boardman, J. W., Bormann, K. J., Deems, J. S., Gehrke, F., Hedrick, A., Joyce, M., Laidlaw, R., Marks, D., Mattmann, C., McGurk, B., Ramirez, P., Richardson, M., Skiles, S. M., Seidel, F. C., and Winstral, A.: The Airborne Snow Observatory: Fusion of scanning lidar, imaging spectrometer, and physically-based modeling for mapping snow water equivalent and snow albedo, Remote Sens. Environ., 184, 139$152,2016$.

Papanicolaou, A. N., Wacha, K. M., Abban, B. K., Wilson, C. G., Hatfield, J., Stanier, C., and Filley, T.: From soilscapes to landscapes: A landscape-oriented approach to simulate soil organic carbon dynamics in intensively managed landscapes, J. Geophys. Res.-Biogeo., 120, 2375-2401, https://doi.org/10.1002/2015JG003078, 2015.

Orem, C. A. and Pelletier, J. D.: The predominance of postwildfire erosion in the long-term denudation of the Valles Caldera, New Mexico, J. Geophys. Res.-Earth, 121, 843-864, https://doi.org/10.1002/2015JF003663, 2016.

Pelletier, J. D., Barron-Gafford, G. A., Guttierez-Jurado, H., Hinckley, E.-L. S., Istanbulluoglu, E., McGuire, L. A., Niu, G.-Y., Poulos, M. J., Rasmussen, C., Richardson, P., Swetnam, T. L., and Tucker, G. E.: Which way do you lean? Using slope aspect variations to understand Critical Zone processes and feedbacks, Earth Surf. Proc. Land., 2017, in press.

Phillips, C. B. and Jerolmack, D. J.: Self-organization of river channels as a critical filter on climate signals, Science, 352, 694-697, 2016.

Quijano, J. C., Kumar, P., Drewry, D. T., Goldstein, A., and Mission, L.: Competitive and Mutualistic Dependencies in Multi-Species Vegetation Dynamics Enabled by Hydraulic Redistribution, Water Resour. Res., 48, W05518, https://doi.org/10.1029/2011WR011416, 2012.

Quijano, J. C., Kumar, P., and Drewry, D.: Passive Regulation of Soil Biogeochemical Cycling by Root Water Uptake, Water Resour. Res., 49, 3729-3746, https://doi.org/10.1002/wrcr.20310, 2013.

Rasmussen, C., Brantley, S. L., Richter, D. deB., Blum, A. E., Dixon, J., and White, A. F.: Strong climate and tectonic control on plagioclase weathering in granitic terrain, Earth Planet. Sc. Lett., 301, 521-530, https://doi.org/10.1016/j.epsl.2010.11.037, 2011.

Rasmussen, C., Pelletier, J. D., Troch, P. A., Swetnam, T. L., and Chorover, J.: Quantifying topographic and vegetation effects on the transfer of energy and mass to the critical zone, Vadose Zone J., 15, 1-16. https://doi.org/10.2136/vzj2014.07.0102, 2015.

Reale, J. K., Van Horn, D. J., Condon, K. E., and Dahm, C. N.: The effects of catastrophic wildfire on water quality along a river continuum, Freshw. Sci., 34, 1426-1442, 2015.

Rempe, D. M. and Dietrich, W. E.: A bottom-up control on freshbedrock topography under landscapes, P. Natl. Acad. Sci. USA, 111, 6576-6581, 2014.

Richardson, M. and Kumar, P.: Critical zone services as environmental assessment criteria in intensively managed landscapes, Earth's Future, 5, 617-632, https://doi.org/10.1002/2016EF000517, 2017.

Richter, D. deB. and Billings, S. A.: 'One physical system': Tansley's ecosystem as Earth's critical zone, New Phytol., 206, 900912, 2015. 
Riebe, C. S., Hahm, W. J., and Brantley, S. L.: Controls on deep critical zone architecture: a historical review and four testable hypotheses, Earth Surf. Proc. Land., 42, 128-156, https://doi.org/10.1002/esp.4052, 2016.

Robertson, G. P., Allen, V. G., Boody, G., Boose, E. R., Creamer, N. G., Drinkwater, L. E., Gosz, J. R., Lynch, L., Havlin, J. L., Jackson, L. E., Pickett, S. T. A., Pitelka, L., Randall, A., Reed, A. S., Seastedt, T. R., Waide, R. B., Wall, D. H.: Long-term Agricultural Research: A Research, Education, and Extension Imperative, BioScience, 58, 640-645, https://doi.org/10.1641/B580711, 2008.

Rue, G. P., Rock, N. D., Gabor, R. S., Pitlick, J., Tfaily, M., and McKnight, D. M.: Concentration-discharge relationships during an extreme event: Contrasting behavior of solutes and changes to chemical quality of dissolved organic material in the Boulder Creek Watershed during the September 2013 flood, Water Resour. Res., 53, 5276-5297, https://doi.org/10.1002/2016WR019708, 2017.

Salve, R., Rempe, D. M., and Dietrich, W. E.: Rain, rock moisture dynamics, and the rapid response of perched groundwater in weathered, fractured argillite underlying a steep hillslope, Water Resour. Res., 48, W11528, https://doi.org/10.1029/2012WR012583, 2012.

St. Clair, J., Moon, S., Holbrook, S., Perron, J. T., Riebe, C. S., Martel, S., Carr, B., Harman, C., Singha, K., and Richter, D. deB.: Geophysical imaging reveals topographic stress control of bedrock weathering, Science, 350, 534-538, https://doi.org/10.1126/science.aab2210, 2015.

Sullivan, P. L., Hynek, S. A., Gu, X., Singha, K., White, T., West, N., Kim, H., Clarke, B., Kirby, E., Duffy, C., and Brantley, S. L.: Oxidative dissolution under the channel leads geomorphological evolution at the Shale Hills catchment, Am. J. Sci., 316, 9811026, 2016.

Swank, W. T. and Crossley Jr., D. A. (Eds.): Forest Hydrology and Ecology at Coweeta, Ecological Studies, 66, Springer-Verlag, New York, 1-14, 1988.

Tennant, C. J., Harpold, A. A., Lohse, K. A., Godsey, S. E., Crosby, B. T., Larsen, L. G., Brooks, P. D., and Van Kirk, R. W.: Regional sensitivities of seasonal snow cover to elevation, aspect, and vegetation structure in western North America, Water Resour. Res., 53, 6908-6926, https://doi.org/10.1002/2016WR019374, 2017.

U.S. Committee on Integrated Observations for Hydrologic and Related Sciences: Integrating Multiscale Observations of U.S. Waters, National Academies Press, Washington D.C., 2008.

U.S. National Research Council: Landscapes on the Edge: New Horizons for Research on Earth's Surface, The National Academies Press, Washington, D.C., 2010.

U.S. National Research Council Committee on Basic Research Opportunities in the Earth Sciences: Basic Research Opportunities in Earth Science, National Academy Press, Washington, D.C., 2001.

U.S. Steering Committee for Frontiers in Soil Science: Frontiers in Soil Science Research, U. S. National Academies Press, Washington, D.C., 2009.
Van Haveren, B. P.: A re-evaluation of the Wagon Wheel Gap Forest Watersehd Experiment, Forest Science, Forest Sci., 34, 208-214, 1988.

Vanderbilt, K. and Gaiser, E.: The international long term ecological research network: a platform for collaborations, Ecosphere, 8, e01697, https://doi.org/10.1002/ecs2.1697, 2017.

Vrettas, M. D. and Fung, I. Y.: Toward a new parameterization of hydraulic conductivity in climate models: Simulation of rapid groundwater fluctuations in Northern California, J. Adv. Model. Earth Syst., 7, 2105-2135, 2015.

Warkentin, B. P. (Ed.): Footprints in the Soil: People and Ideas in Soil History, Elsevier, Amsterdam, 2006.

Weber, C. F., Lockhart, J. S., Charaska, E., Aho, K., and Lohse, K. A.: Bacterial composition of soils in ponderosa pine and mixed conifer forest exposed to different wildfire burn severity, Soil Biol. Biochem., 69, 242-250, 2014.

West, N., Kirby, E., Bierman, P. R., and Clarke, B. A.: Aspectdependent variations in regolith creep revealed by meteoric ${ }^{10} \mathrm{Be}$, Geology, 42, 507-510, https://doi.org/10.1130/G35357.1, 2014.

White, T., Brantley, S., Banwart, S., Chorover, J., Dietrich, W., Derry, L., Lohse, K., Anderson, S., Aufdendkampe, A., Bales, R., Kumar, P., Richter, D., and McDowell, B.: The role of critical zone observatories in critical zone science, in: Principles and Dynamics of the Critical Zone, Developments in Earth Surface Processes, vol. 19, edited by: Giardino, R. and Hauser, C., Elsevier, chap. 2, 2015.

White, T. and Sharkey, S.: Critical Zone, in: Oxford Bibliographies in Environmental Science, edited by: Wohl, E., Oxford University Press, New York, 2016.

White, T., Wymore, A., Dere, A., Hoffman, A., Washburne, J., and Conklin, M.: Integrated interdisciplinary science of the Critical Zone as a foundational curriculum for addressing issues of sustainability, Journal of Geoscience Education, 65, 136-145, 2017.

Woo, D. K. and Kumar, P.: Role of micro-topographic variability on age of soil nitrogen in intensively managed landscape, Water Resour. Res., 53, 8404-8422, https://doi.org/10.1002/2017WR021053, 2017.

Yan, Q., Iwasaki, T., Stumpf, A. J., Parker, G., Belmont, P., and Kumar, P.: Hydrogeomorphological understanding of alluvial river valley development in glaciated landscapes, Earth Surf. Proc. Land., esp.4234, https://doi.org/10.1002/esp.4234, 2017.

Zapata-Rios, X., Brooks, P. D., Troch, P. A., McIntosh, J., and Rasmussen, C.: Influence of climate variability on water partitioning and effective energy and mass transfer in a semiarid critical zone, Hydrol. Earth Syst. Sci., 20, 1103-1115, https://doi.org/10.5194/hess-20-1103-2016, 2016.

Zhang, Z., Glaser, S. D., Bales, R. C., Conklin, M., Rice, R., and Marks, D. G.: Technical report: The design and evaluation of a basin-scale wireless sensor network for mountain hydrology, Water Resour. Res., 53, 4487-4498, https://doi.org/10.1002/2016WR019619, 2017. 